\title{
Beyond fixes that fail: identifying sustainable improvements to tree seed supply and farmer participation in forest and landscape restoration
}

\author{
Michel Valette $^{1,2}$, Barbara Vinceti $^{3}{ }$ Nestor Gregorio $^{4}{ }^{4}$ Arwen Bailey $^{3}$ Evert Thomas $^{5}$ and Riina Jalonen $^{1}$
}

\begin{abstract}
Growing evidence suggests that constraints to the availability and quality of tree seed can undermine the success of forest and landscape restoration efforts and the delivery of associated benefits such as mitigating climate change and halting biodiversity loss. Past experiences to promote tree seed supply have frequently shown limited outcomes over time, partly because of unexpected, deleterious dynamics that emerged from the interventions themselves. In this study, we used a dynamic system approach to understand the interrelated problems that constrain the supply of good quality and site-adapted tree seeds to meet smallholders' and other stakeholders' demand in Burkina Faso and the Philippines, and to identify leverage points for intervention. Causal loop diagrams were constructed for each country, based on a framework of indicators of effective tree seed supply systems, literature review, semistructured interviews, and expert validation. The diagrams illustrate the complex interactions between planned interventions and their expected and unexpected effects that frequently lead to adverse outcomes. For example, the high turnover of forestry officers in municipalities to combat corruption in Burkina Faso combined with limited resources to support smallholders undermined the officers' ability to strengthen local capacities in seedling production and sustainable forest management. In the Philippines, the imposition of rigid requirements for seedling survival rates as a condition for funding, in the absence of adequate time and resources for the production of quality seedlings and monitoring, resulted in exaggerated survival rates during reporting, which in turn hampered the detection and addressing of shortcomings. A dynamic system approach can help stakeholders recognize the broader impacts of their actions and jointly identify appropriate interventions, from developing more context-specific approaches to reconsidering investment criteria to balance benefits.
\end{abstract}

Key Words: forest landscape restoration; genetic diversity; smallholder involvement; system archetypes; system dynamics

\section{INTRODUCTION}

Restoration of tree cover has gained momentum in multilateral environment agreements owing to its enormous promise for mitigating both the global climate and biodiversity crises (Alexander et al. 2011, Ciccarese et al. 2012, Pistorius and Freiberg 2014). Assisted natural regeneration holds vast potential to help scale up restoration efforts and promote biodiversity conservation, because it is generally less expensive than active planting and favors the establishment of native species (Chazdon and Guariguata 2016). However, active tree planting is required under specific habitat conditions, such as in sites with depleted seed banks, impoverished soils, or to pursue specific socioeconomic goals (Shono et al. 2007, Brancalion et al. 2016).

While countries strive to scale up forest and landscape restoration (FLR), serious concerns continue to exist about the availability and supply of high-quality seeds to meet planting needs (Broadhurst et al. 2016). Tree seed supply refers to the collection, production, distribution, and quality control of reproductive material of trees, including seeds, seedlings, wildlings, and vegetatively propagated materials (Nyoka et al. 2015). Limited access to quality seed, including genetically diverse seeds or improved material from breeding programs, as well as inadequate matching of the right seed provenances to planting sites have constrained success of smallholders' tree planting in developing countries. The use of inadequate seed sources and narrow genetic diversity is pervasive (Jalonen et al. 2018), jeopardizing the longterm survival, productivity, adaptive capacity, and future reproductive success of restored tree populations (Alfaro et al. 2014, Thomas et al. 2014, Roshetko et al. 2018).
Past interventions to address seed availability and quality in restoration efforts have sometimes led to unexpected outcomes. For example, distributing free seedlings produced outside of the interventions areas or establishing project nurseries can undermine the development of local seedling markets (Graudal and Lillesø 2007, Roshetko et al. 2018). In Brazil, imposing legal requirements on species diversity and seed source accreditation for nurseries unintentionally impeded small seed producers' access to formal seed markets because of elevated costs (de Urzedo et al. 2019). Lack of knowledge and awareness of the benefits of quality seeds may reduce people's willingness to pay for premium seeds and at the same time disincentivize seed collectors from applying good seed selection criteria (Roshetko et al. 2008, Cornelius and Miccolis 2018). The ambitious FLR targets around the world may increase the likelihood of meeting seed demand through quick fixes that may not increase the availability or use of good quality seeds in the long term.

Dynamic system approaches help understand and address feedback effects, delays, and properties of a given system arising from the interaction of multiple variables that could not be detected if the same variables were observed in isolation (Liu et al. 2007, Zexian and Xuhui 2010). Through these approaches, it is possible to track patterns in variable dynamics that can be associated with intended actions and unintended results and are common to many systems, known as system archetypes (Senge 1994). Identification of system archetypes helps diagnose root causes of undesirable outcomes of dynamic systems and identify appropriate solutions (Wolstenholme 2003). Through the creation of models that integrate different perspectives and sources of information across disciplines (Forrester 1971, Hjorth and

${ }^{1}$ Bioversity International, Serdang, Malaysia, ${ }^{2}$ Center for Environmental Policy, Imperial College of London, London, UK, ${ }^{3}$ Bioversity International, Rome, Italy, ${ }^{4}$ University of the Sunshine Coast, ${ }^{5}$ Bioversity International, Lima, Peru 
Table 1. Characteristics of forest resources and organization of tree seed supply in the two countries examined.

\begin{tabular}{|c|c|c|}
\hline Characteristics & Burkina Faso & Philippines \\
\hline Restoration commitments & 5 Mha by 2030 ( $18 \%$ of the country area) & 7.1 Mha by $2028(20 \%$ of the country area) \\
\hline Remaining forest area & 5.35 Mha $(19,6 \%)$ & 8.04 Mha $(27 \%)$ \\
\hline Geography & Landlocked country & Archipelago \\
\hline Climate & Semiarid & Tropical \\
\hline Influence of the international timber trade & None & $\begin{array}{l}\text { Switched from a net exporter to net importer in the } \\
\text { 1970s because of a reduction of forest cover } \\
\text { (Grainger and Malayang 2006) }\end{array}$ \\
\hline $\begin{array}{l}\text { Leading implementers of forest and landscape } \\
\text { restoration efforts }\end{array}$ & $\begin{array}{l}\text { Civil society; projects primarily funded/ } \\
\text { implemented by international players and } \\
\text { smallholders }\end{array}$ & $\begin{array}{l}\text { The government through the Enhanced National } \\
\text { Greening Program; and farmer groups }\end{array}$ \\
\hline Research on forest genetic resources & Centralized, led by the National Tree Seed Centre & Fragmented among different institutions \\
\hline Certification system for tree seed sources & $\begin{array}{l}\text { Existing legal requirement, but not yet } \\
\text { implemented }\end{array}$ & $\begin{array}{l}\text { Seed producer accreditation schemes, but weak } \\
\text { implementation (Gregorio et al. 2017) }\end{array}$ \\
\hline Organization of the seed supply system & $\begin{array}{l}\text { The National Tree Seed Centre distributes seeds } \\
\text { through intermediaries (e.g., NGOs, Forest } \\
\text { Department); at the same time, a large number of } \\
\text { smallholders collect local seed on their own }\end{array}$ & $\begin{array}{l}\text { The Forest Department produce seedlings in } \\
\text { regional nurseries and pays community } \\
\text { organizations to produce seedlings }\end{array}$ \\
\hline
\end{tabular}

Bagheri 2006), dynamic system approaches can support multistakeholder communication and decision making, and improve stakeholders' understanding of the outcomes of their actions (Doyle and Ford 1998, Hirsch et al. 2007, Nicholson et al. 2020). Dynamic system approaches also allow simulating the evolution of a system over time. This approach has frequently been used to help improve ecosystem management strategies and interventions, for instance, to analyze deforestation dynamics in the Amazon (Portela and Rademacher 2001), water scarcity in Australia (Sahin et al. 2015), dissemination of high-quality crop seed in Uganda (Reinker and Gralla 2018), and sustainable agricultural development in Ghana (Banson et al. 2016).

Here, we apply the dynamic system approach to study how tree seed supply could be improved to support FLR commitments in developing countries, mainly through greater participation of local community members. Drawing on extensive data from Burkina Faso and the Philippines, both of which have set large national targets for FLR, our objectives were to (1) describe the interacting elements and underlying dynamics in seed supply systems in the two countries, and (2) identify leverage points to improve the supply of and demand for diverse, quality tree seed in FLR. We discuss lessons learned from the two case studies and their applicability to other contexts.

\section{METHODS}

\section{Case studies}

Burkina Faso and the Philippines share similar quantitative targets for FLR, but they face different challenges owing to their environmental characteristics and how their tree seed supply systems are organized (Table 1). In Burkina Faso, FLR is mostly carried out by local, national, and international actors and the state plays a coordinating role. Smallholder farmers and nongovernmental organizations (NGOs) are expected to play a major role in reaching national FLR targets, including through sourcing their planting material. On the other hand, some projects and NGOs have been buying seeds from the National Tree Seed Center (Centre Nationale de Semences Forestières, CNSF), which also acts as the primary research institute on forest seeds and genetic resources in Burkina Faso. The seed supply system has a mix of characteristics: an independent model, where FLR actors independently organize seed supply to meet their needs, and a state-run model, where the government is responsible for all aspects of seed supply to meet national commitments (Atkinson et al. 2018). In the Philippines, the state plays a significant role in funding and implementing the FLR efforts. Nationwide forestry programs, including the enhanced National Greening Program for forest restoration (eNGP, 2017-2028), source some of the seed needed from smallholders and farmer groups through supply contracts, while the rest of the seed is produced by the Forest Department (Gregorio et al. 2017). The system represents a mix of a state-run seed supply model and an incentives-led model, where networks of independent actors respond to government incentives for producing seeds (Atkinson et al. 2018).

\section{Problem framing and causal loop diagram construction}

Causal loop diagrams were constructed for each country to identify factors that prevent or enable a "fit-for-purpose" tree seed supply, i.e., a system where seeds of diverse species are available, adapted to local growing conditions and end-users' needs, and can adapt to future climatic conditions (Atkinson et al. 2018). Key components of the diagrams and related terms are explained in Tables 2 and 3. To include all dynamics related to seed production and use within the boundaries of our analysis, the diagrams were constructed at the national scale, including aspects of national policies and findings from field research from literature and authors' own work (e.g., Valette et al. 2019). The resulting causal loop diagrams do not necessarily represent any specific context within the two countries, but rather an array of dynamics whose presence and importance may vary across contexts. Some localized dynamics were included as examples of "bright spots" that may offer valuable lessons on how to strengthen positive feedback loops (Biggs 2007).

The diagrams were developed through a five-step approach (Fig. 1). First, a conceptual framework was designed to ensure all critical aspects were included. To assess the ability of tree seed supply to meet the demand for FLR efforts, we used a set of 15 indicators developed and applied in seven Latin American 
Table 2. Glossary of the terms used in this article.

\begin{tabular}{ll}
\hline \hline Terms & Definitions \\
\hline Causal loop diagram & $\begin{array}{l}\text { Visual representation of the links between feedback loops and isolated variables, enabling the dynamics of the } \\
\text { variables and the potential effects of interventions to be inferred }\end{array}$ \\
Andicators & $\begin{array}{l}\text { Attributes of functional tree seed supply systems identified by Atkinson et al. (2018), systematically examined during } \\
\text { literature review to identify strengths and weakness of tree seed supply for forest landscape restoration (see Table } \\
\text { A1.1) }\end{array}$ \\
Factors influencing seed supply or demand, which can vary in extent or intensity; basic components of the causal \\
loop diagram \\
Relationship between two variables evolving in the same direction (if one variable increases, the other increases too); \\
bimilar relationship & $\begin{array}{l}\text { Relationship between two variables evolving in the opposite directions (if one variable increases, the other decreases); } \\
\text { basic elements of the causal loop diagram }\end{array}$ \\
Opposite relationship & A group of variables connected as a loop, so that each variable is both a consequence and a cause of other variables \\
& Feedback loops composed of variables strengthening each other so that they continually grow or decline over time \\
Feedback loop & Feedback loops composed of antagonist variables, so that they stabilize or stagnate over time \\
Reinforcing feedback loop & Group of feedback loops around a similar theme \\
Balancing feedback loop &
\end{tabular}

countries by Atkinson et al. (2018). The authors identified five conditions for having functional fit-for-purpose seed supply: (i) the selection of appropriate species for planting and seed sources is supported by scientific information; (ii) (improved) planting materials of representative subsets of native species and seed sources from all ecosystems in the country are being collected; (iii) there is a demand for, and access to, a variety of planting material of native species; (iv) an effective quality control system exists; and (v) a favorable enabling environment is created, with appropriate legislation, which supports funding opportunities and capacity building. Given the emphasis in national policies and strategies in both countries on the need to involve smallholders in FLR efforts (MEEVCC 2010, DENR 2015), five indicators reflecting this aspect were added, bringing the total number of indicators to 20 (Appendix 1, Table A1.1). The additional indicators were related to (i) income opportunities for local communities, (ii) stability of seed demand, (iii) access to knowledge and markets by producers, (iv) capitalization on past experiences, and (v) continuity of interventions.

Data on the indicators were gathered through an in-depth literature review and interviews and surveys targeting FLR stakeholders in the two countries. Causal loop diagrams were then created using Kumu software (https://kumu.io). Variables were organized in feedback loops based on evidence of how they related to each other. The feedback loops were then grouped thematically to facilitate the interpretation of the diagrams.

The resulting causal loop diagrams were reviewed by FLR stakeholders and researchers from the two countries. Feedback was collected from 12 stakeholders (Fig. 1), some also involved in the initial steps of model design. Using the causal loop diagrams as heuristic, respondents described patterns of stakeholder involvement, issues, viable solutions, and experiences from past restoration initiatives, bringing a perspective that is usually not well captured in the scientific literature. Finally, once the causal loop diagrams were finalized, system archetypes and their corresponding potential leverage points were identified in each diagram (Table 3; Senge 1994; W. Braun 2002, unpublished manuscript, https://www.albany.edu/faculty/gpr/PAD724/724WebArticles/ sys archetypes.pdf).

\section{RESULTS}

In Burkina Faso, nine thematic sections were identified in the causal loop diagrams, representing the broader dynamics that affect the quality and availability of, and access to, tree seed and seedlings for restoration: (i) centralization of seed production; (ii) civil society support to tree planters; (iii) farmer nursery networks; (iv) preference for exotic species; (v) the quality of the planting material used; (vi) short project funding cycles; (vii) competition for forest resources versus collaborative actions; (viii) emphasis on law enforcement versus promoting compliance; and (ix) enforcing forest protection to prevent further degradation.

In the Philippines, eight thematic sections were identified: (i) congruence between goals and funding; (ii) resourcing of local government officers; (iii) sustainability of people's organizations; (iv) conservation of natural seed sources; (v) preference for exotic species; (vi) private nursery sector; (vii) central regional nurseries; and (viii) local knowledge diffusion.

A detailed description of the thematic sections can be found in Appendix 2 (Table A2.1) and of the information sources used in Appendix 3. A complete visualization of the causal loop diagrams are available for Burkina Faso at https://embed.kumu.io/ b260c9f20c884628a62096891f8a657e and for the Philippines at https://embed.kumu.io/5fb9a2720dd3698a4eb66315341eaaee. Six of the thematic sections are described in further detail below, representing both dynamics specific to each country, and dynamics that were common to both countries and likely to be relevant in a broad range of geographical contexts.

\section{Examples of dynamics in Burkina Faso}

\section{Attitude of the Forest Department}

Forest Department officers represent an important link between national policies and their local implementation, but their limited capacity regarding quality seed production (Fig. 2, loop 1) and their short residency in each community (Fig. 2, loop 4) constrain their ability to effectively support smallholders in tree planting (Fig. 2, loop 3). According to the rules of the Forest Department, officers can be posted in each community for a limited time only, in an attempt to combat corruption. Typical consequences of these constraints are: " 
Table 3. Archetypes identified in the causal loop diagrams and their proposed solutions (Senge 1994, Braun 2002).

\begin{tabular}{|c|c|}
\hline System archetype & $\begin{array}{l}\text { Generic patterns of behavior, over time, of variables in a dynamic system, where unintended consequences } \\
\text { appear after a delay. Archetypes are symptomatic of deeper issues within the systems. The following are all } \\
\text { different system archetypes. }\end{array}$ \\
\hline Growth and underinvestment & $\begin{array}{l}\text { A system where growth can, at the beginning, be reached with a limited initial investment, but quality then } \\
\text { stagnates and declines without further investments. Solutions consist of changing how decisions for investments } \\
\text { are made and providing up-to-date and relevant information. }\end{array}$ \\
\hline Escalation & $\begin{array}{l}\text { The actions of one actor are perceived as a threat by another, who will overreact in response. Solutions consist of } \\
\text { enabling a shift from competition between actors to cooperation. }\end{array}$ \\
\hline Shifting the burden & $\begin{array}{l}\text { Simple solutions addressing the symptoms of a deep issue are implemented, but the primary problem is ignored } \\
\text { because addressing it is more complex. Solutions consist in exploring the issues from a different perspective, } \\
\text { identifying the causal factors and implementing appropriate solutions. }\end{array}$ \\
\hline Tragedy of the commons & $\begin{array}{l}\text { Individuals overexploit a common pool of resources for short-term individual benefits and overlook or ignore } \\
\text { the cumulative consequences of each individual's actions on it. Solutions consist of minimizing negative effects } \\
\text { of short-term individual rewards on the sustainability of common pool resources in the long term. }\end{array}$ \\
\hline Fixes that fail & $\begin{array}{l}\text { A quick-fix solution to a problem works initially but creates deleterious effects over time and may worsen the } \\
\text { situation. Solutions consist in recognizing the ineffectiveness of the fix tried, identifying the causal factors, and } \\
\text { finding and applying appropriate solutions. }\end{array}$ \\
\hline Limits to success & $\begin{array}{l}\text { A limiting factor is initially not constraining growth, but over time ends up preventing further improvement. } \\
\text { Solutions consist in identifying the pressure that is building up with growth and finding solutions to relieve this } \\
\text { pressure. }\end{array}$ \\
\hline Success to the successful & $\begin{array}{l}\text { A person or a group receives more resources than others from the beginning, gains a competitive advantage and } \\
\text { tends to be favored over time. Solutions consist in identifying how resources are distributed among people or } \\
\text { groups and applying measures to encourage collaboration instead of competition. }\end{array}$ \\
\hline
\end{tabular}

1. Forest officers interact with only a few people in each community during the development of forest management plans (Fig. 2, loop 1). This asymmetry creates tensions between smallholders and reinforces overexploitation of common forest resources (Fig. 2, loop 5). This dynamic strengthens the focus of the Forest Department on repression rather than supporting smallholders, reducing community members' trust in forest officers (shifting the burden)."

2. Limited advice is given to smallholders on silvicultural techniques (Fig. 2, loop 2), constraining their income opportunities from tree planting. Smallholders receive little guidance on the importance of seedling quality and on best practices for seed collection and seedling production (Fig. 2 , loop 6), resulting in declining interest to seek advice from forest officers."

3. Smallholders see little benefit from registering as nursery owners with the Forest Department, which reduces their interest to approach the Department (Fig. 2, loop 3.) but also excludes them from receiving assistance. This hinders both the development of an information system of private nurseries that would benefit from government support, e.g., capacity strengthening and seed orders by government projects, and the application of quality control measures.

Organization of seedling producers into networks

The difficulties faced by small-scale seedling producers in ensuring long-term profitability of nurseries, due to the small size of their business and their scattered customers, has led seedling producers in the Central Region of Burkina Faso to create informal networks (Fig. 3, loop 2). In this way, nursery owners support each other by sharing knowledge, collaborate in responding to small orders of seedlings for different species by scattered customers, and derive more profits: "
1. Seedling producers have access to multiple sources of information on seed production, including forest officers and other smallholders, and experiment on their own. Networks of seed producers are often led by nodal smallholders who are more experienced in seed production, sometimes have benefited from formal training, and help other network members with tree planting and nursery activities (Fig. 3, loop 2). Information sharing extends beyond the network and can help other smallholders access the knowledge necessary to venture into nursery activities. These knowledge exchanges foster good cooperation among producers."

2. Having groups of seedling producers organized in informal networks as counterparts makes it easier for NGOs and other FLR agents to distribute support effectively, for example, reinforcing capacity on nursery management and seed harvesting or preordering planting materials (Fig. 3, loops 5 and 6). Thanks to their increased capacity and an improved planning of seedling production, the nurseries become reliable sources of planting material for FLR projects. Moreover, increased capacity likely results in a higher quality of the planting material used, improving chances of success of FLR interventions and demonstrating the benefits of employing good quality planting material (Fig. 3, loop 7)."

3. Seedling producers can cooperate in sharing information on tree seed sources, collecting seed, ordering seed in bulk from distributors and exchange seeds (Fig. 3, loop 2). These activities reduce the time required for seed collection and enable producing seedlings for more species, thus allowing seedling producers to become reliable suppliers and increase the orders they handle (Fig. 3, loop 4). Collective seed sourcing also results in pooling of seed from many parent trees, enhancing intraspecific diversity in seed lots, especially 
Fig. 1. Stepwise approach for the development and analysis of causal loop diagrams. More details on the sources of information used can be found in Appendix 3. The number in brackets represent the number of stakeholders interviewed.

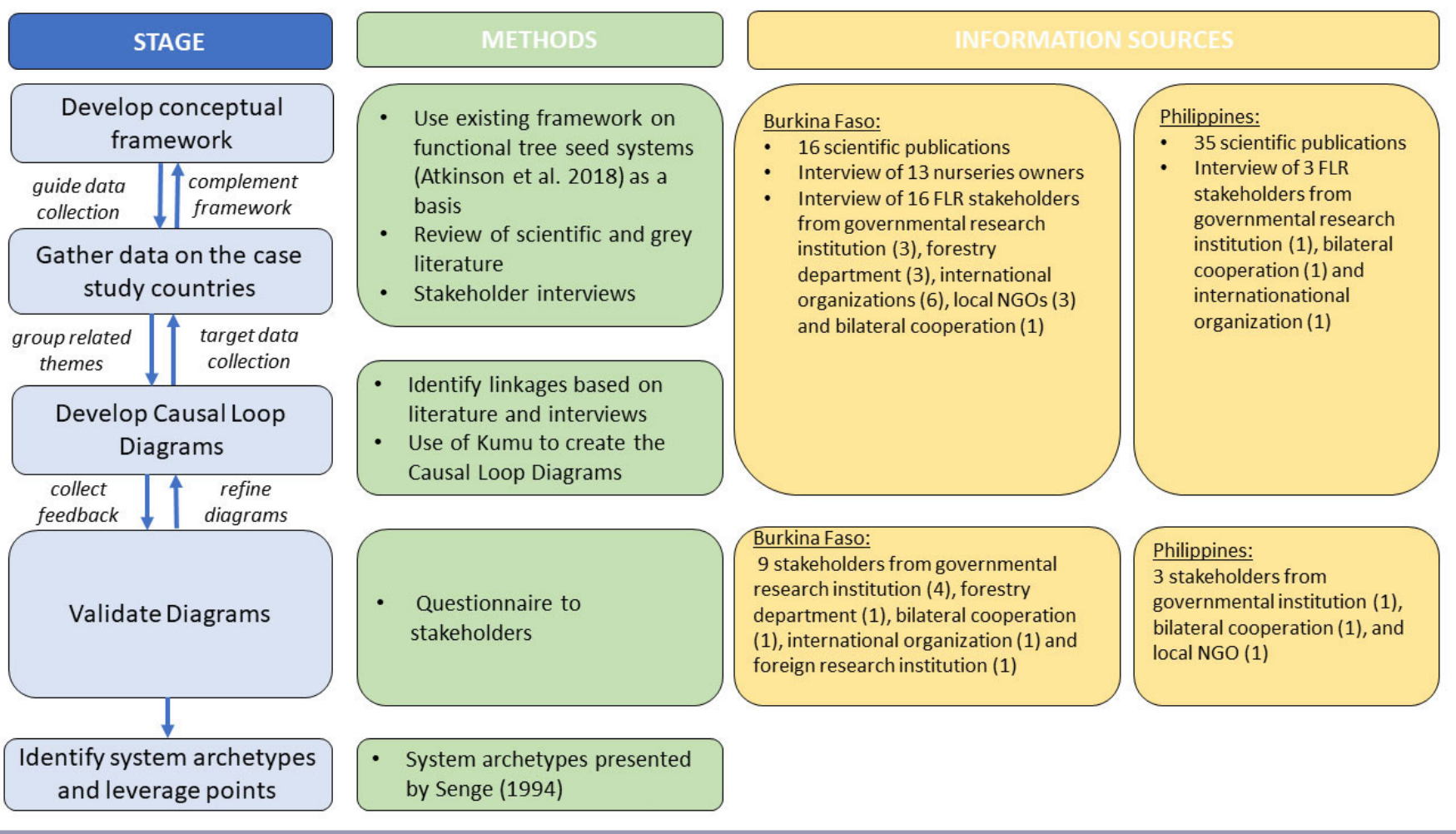

if network members have received relevant training and apply seed collection guidelines (Fig. 3, loop 7)."

4. Individual seedling producers who participate in a network are better able to fulfil customers' orders by collaborating in seed collection and production; this reduces the need for potential customers to produce seed themselves if they can pay (Fig. 3, loop 3). Being part of a network also enables individual seedling producers to specialize in handling fewer species, thus reducing financial risks linked to production.

\section{Examples of dynamics in the Philippines}

\section{Allocation of funds under the enhanced National Greening Program (eNGP)}

The strong commitment to FLR in the Philippines is implemented through the eNGP. Available funds are channeled to implementers through the Department of Environment and Natural Resources (DENR), which oversees program planning, implementing, and monitoring. DENR central offices decide on budget allocation and program design (Fig. 4, loop 3). This decision-making structure creates several constraints: "

1. The ambitious FLR targets require large quantities of seed, but insufficient budget is allocated to ensuring quality control. This results in infrequent audits and frequent use of low-quality seed from nonaccredited seed producers (Fig. 4, loop 5), which in turn hinders the success of long-term restoration (growth and underinvestment)."
2. Insufficient funding is allocated to strengthening the capacity of people's organizations (POs) that are expected to produce part of the seeds required by the eNGP, because of the assumption that enough capacity in this area was already developed through past forestry training programs. This weakens local communities' ability to produce the highquality seedlings needed for the eNGP and sustains DENR's need to continue sourcing them from elsewhere (Fig. 4, loop 7 , growth and underinvestment)."

3. Lower administrative units within DENR are excluded from decisions on fund allocations (Fig. 4, loop 2). This results in insufficient financing for consultations with local communities during the planning and a limited use of local knowledge about seed collection (Fig. 4, loop 1). DENR has introduced size requirements for seedlings to be used in the eNGP ( $\geq 30 \mathrm{~cm}$ of height, $\geq 5 \mathrm{~mm}$ base diameter, and $\geq 6$ leaves) to reduce seedling mortality. However, poor program planning and late orders from DENR to local communities have led to extensive use of wildlings to meet size requirements. The root system of wildlings is often damaged during collection, which, together with a short recovery time in nurseries before planting, can lead to poor growth (Fig. 4 , loop 8, fixes that fail)."

4. DENR distributes free seedlings of the same species as those produced by communal and private nurseries, undermining the sustainability of local seedling markets, preventing the 
Fig. 2. Section of causal loop diagram on the dynamics linked to the role of the Forest Department in tree seed supply in Burkina Faso. The labels in bold indicate the names of the feedback loops. The continuous green arrows correspond to the similar relationship between variables (when one variable increases, so does the other), and the red dashed arrows correspond to inverse relationship (when one variable increases, the other decreases). Some elements have been excluded from the figure for clarity. The complete map is presented in https://embed.kumu.io/b260c9f20c884628a62096891f8a657e, and explanations of feedback loops are included in Appendix 3.

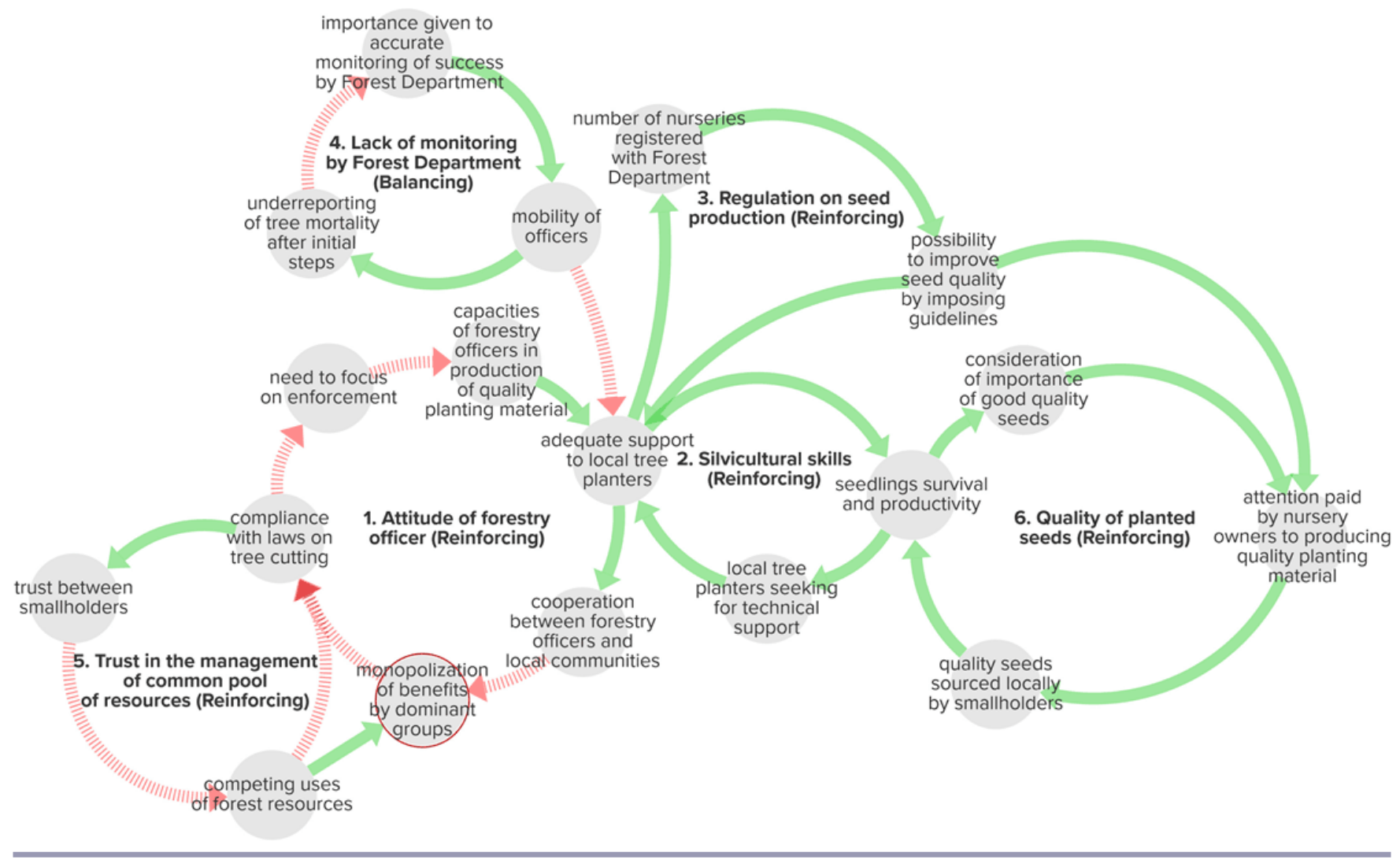

emergence of a profitable private nursery sector independent from eNGP funding, and creating local shortages of seed (Fig. 4, loop 6, shifting the burden)."

5. Strict requirements set by the Forest Department's central office for minimum seedling survival rates $(\geq 85 \%)$, as a precondition to funding disbursement, lead to the reporting of inflated survival rates. This hinders learning from past experiences to understand success factors in implementation, seed quality being one. The subsequent failures encourage DENR to impose minimum survival rates on local implementers (Fig. 4, loop 4, fixes that fail)

Sustaining the long-term functionality of people's organizations Maintaining the functionality of the POs in the long term, to ensure restoration and long-term management of forests, has proven difficult because of several interrelated issues: "

1. Opportunities to access public land for income generation from seedling production and tree planting attracts smallholders to participate in PO, but large groups require strong leadership for an effective cooperation among members. The difficulties faced by PO leaders in maintaining cohesion can undermine their capacity and long-term interest to lead (Fig. 5, loop 1, limits to success)."

2. Lack of long-term income prospects results in the members leaving the PO over time, especially those who are unable to bear the opportunity costs. The few remaining members take hold of the decision-making power. When new funding opportunities emerge, they tend to employ other smallholders as workforce instead of sharing the benefits equally among all PO members, undermining future collaboration opportunities (Fig. 5, loop 2, fixes that fail)."

3. The lack of cooperation between PO members reduces possibilities to reach private sector and other clients beyond the eNGP. PO income depends on funds from state programs, and their generally short duration prevents the development of capacities in seed production and marketing (Fig. 5, loops 3 and 4, shifting the burden)"

4. Lack of long-term PO membership hampers opportunities for collaborative learning from past experiences and cripples the trust of DENR in PO. This leads to fewer contract 
Fig. 3. Section of causal loop diagram representing the dynamics seedling producers organized into networks, in Burkina Faso. The labels in bold indicate the feedback loops. For the interpretation of the symbols please refer to the caption of Figure 2. Some elements have been excluded from this figure for clarity. The complete map is presented in https://embed.kumu.io/ b260c9f20c884628a62096891f8a657e, and explanations of feedback loops are included in Appendix 3.

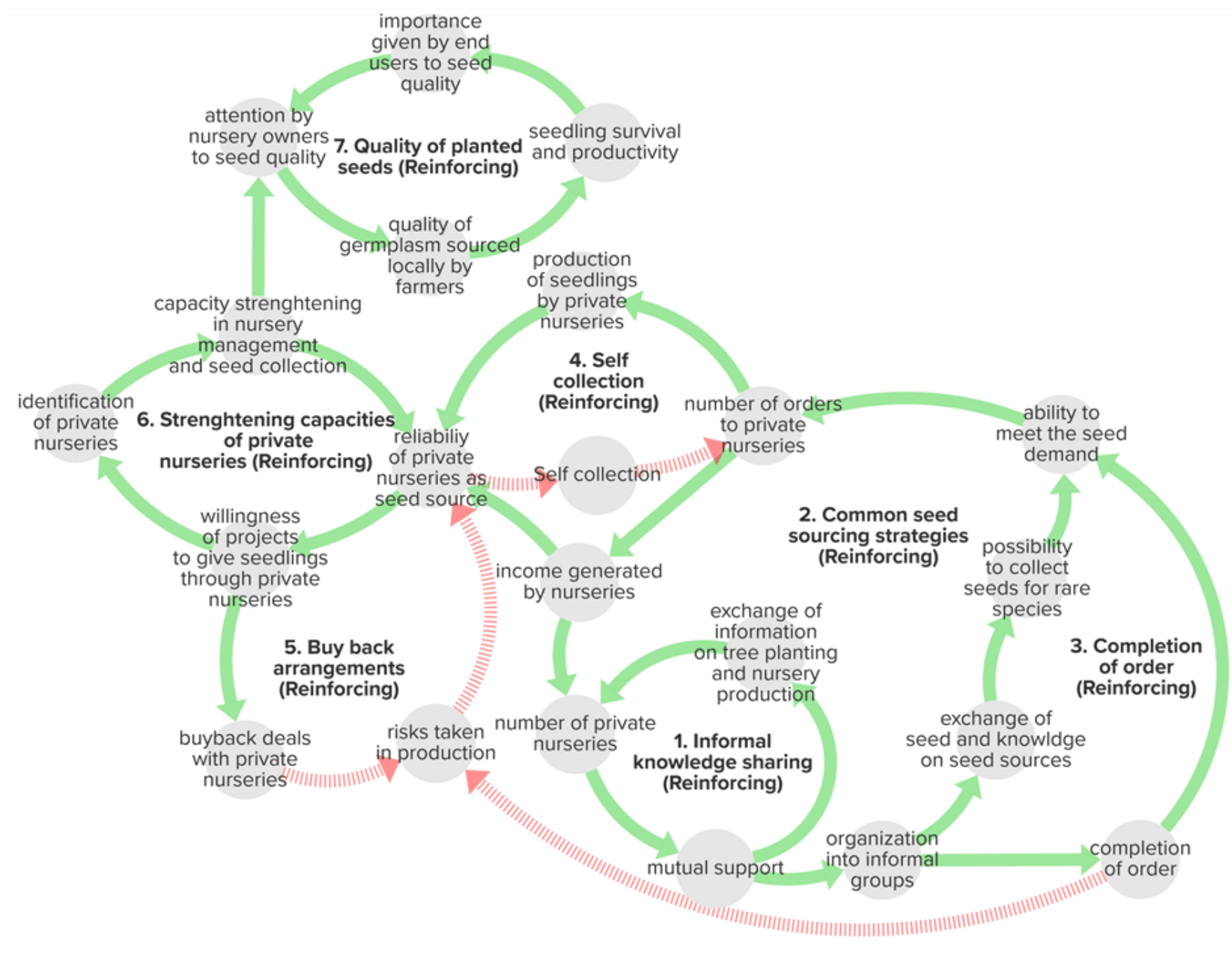

opportunities for POs for activities associated with the eNGP and reduced long-term funding (Fig. 5, loop Ff5).

\section{Predominance of exotic species in tree planting}

In both case study countries, exotic tree species represent a large proportion of the trees used in restoration efforts (see Appendix 2, Table A2.1). Early investment in exotic species has created a "success to the successful" dynamic to the detriment of local species; for exotic species improved seed sources exist, seed collection and seedling production are more profitable, and seeds are available to smallholders, as we illustrate below.

In Burkina Faso, exotic tree species (e.g., Eucalyptus camaldulensis, Mangifera indica, Anacardium occidentale) have been used for various benefits (Appendix 1, Fig. A1.1). The main motivation for tree planting is economic gain: smallholders are generally willing to pay premium prices for high-quality seed of high-value species such as fruit trees. Still, they are reluctant to do so for species for which there is less evidence on the relationship between seed quality and the quality of the harvested products. Consequently, seedling producers focus on well-known, easy-togrow and often exotic species for which an important market exists. There are also cultural constraints against planting native tree species, some of which are believed to be inhabited by spirits. Pressure on natural populations of valuable nontimber forest product (NTFP) species is maintained partly because of the limited planting efforts for these species. This also means limited seed availability for valuable native tree species compared to exotic species.

In the Philippines, similar contrasts exist between the availability of seed of exotic and native tree species. Seed demand is driven by income opportunities related to the industrial market for timber, which has often been met by planting exotic tree species (Appendix 1, Fig. A1.2). Perceived benefits from existing 
Fig. 4. Causal loop diagram of the dynamics linked to the allocation of funds for the enhanced National Greening Program (eNGP) in the Philippines. The labels in bold indicate the feedback loops. For the interpretation of symbols, please refer to the caption of Figure 2. PO: people's organization; DENR: Department of Environment and Natural Resources. Some elements have been excluded from the figure for clarity. For the complete map, refer to https://embed.kumu.io/5fb9a2720dd3698a4eb66315341eaaee, and explanations of feedback loops are included in Appendix 3.

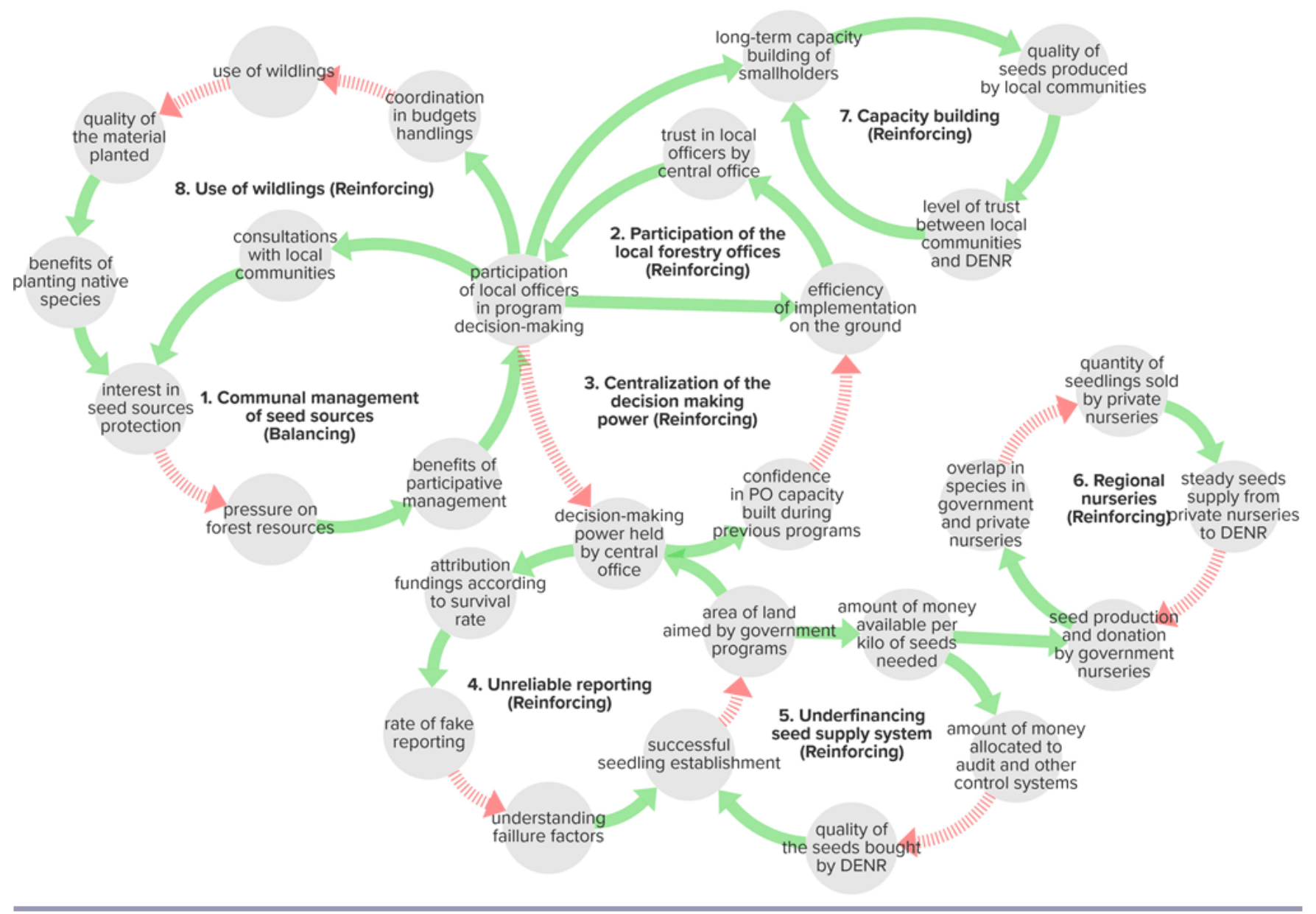

plantations influence the species choice of smallholders; hence they usually prefer exotic species, including Acacia mangium, Gmelina arborea, and Swietenia macrophylla. Past research efforts have focused on the development of improved seeds and silviculture techniques for commonly used exotic species, further boosting their productivity. In contrast, research on native species has been scarce. This widens the comparative advantage in favor of exotic trees. Moreover, the lack of adequate seed sources for native tree species and irregular fruiting leads to the collection of wildlings, whose survival is often compromised by transplanting, which only increases the gap in profitability between native and exotic species.

\section{Conservation of seed sources}

In both countries, choices around forest governance and management are critical to determine the future of the remaining forest resources, including seed sources of native trees, which could either be protected through community involvement or continue to be overexploited (tragedy of the commons, see Appendix 2, Table A2.1).
In Burkina Faso, the scarcity of forest resources and lack of trust between smallholders in the management of common-pool resources weaken the application of customary laws on harvesting forest products and lead to overexploitation of the resources, which then further reduces trust among smallholders (Appendix 1, Fig. A1.3). Overexploitation tends to concentrate on the most valuable species, significantly limiting their seed availability. With the reduction of forest cover, land uses incompatible with natural regeneration of trees, e.g., pastures, mining, and cultivation of cash crops, can offer profitable alternative income opportunities but often lead to soil degradation further constraining natural regeneration. On the other hand, FLR can be seen as a solution to soil degradation and promoting tree establishment can occur also through farmer-managed natural regeneration. However, this practice may be constrained by the workload and materials required.

In the Philippines, pressures on forest resources result partly from a nationwide shortage of industrial wood (Appendix 1, Fig. A1.4). The DENR could impose strict regulations on logging and tree 
Fig. 5. Causal loop diagram of the dynamics linked to the long-term efficiency of people's organizations in the Philippines. The labels in bold indicate the feedback loops. For the interpretation of symbols, please refer to the caption of Figure 2. PO: people's organization; DENR: Department of Environment and Natural Resources. Some elements have been excluded from the figure for clarity. For the complete map, refer to https://embed.kumu.io/5fb9a2720dd3698a4eb66315341eaaee, and explanations of feedback loops are included in Appendix 3.3. Examples of dynamics common to both case studies

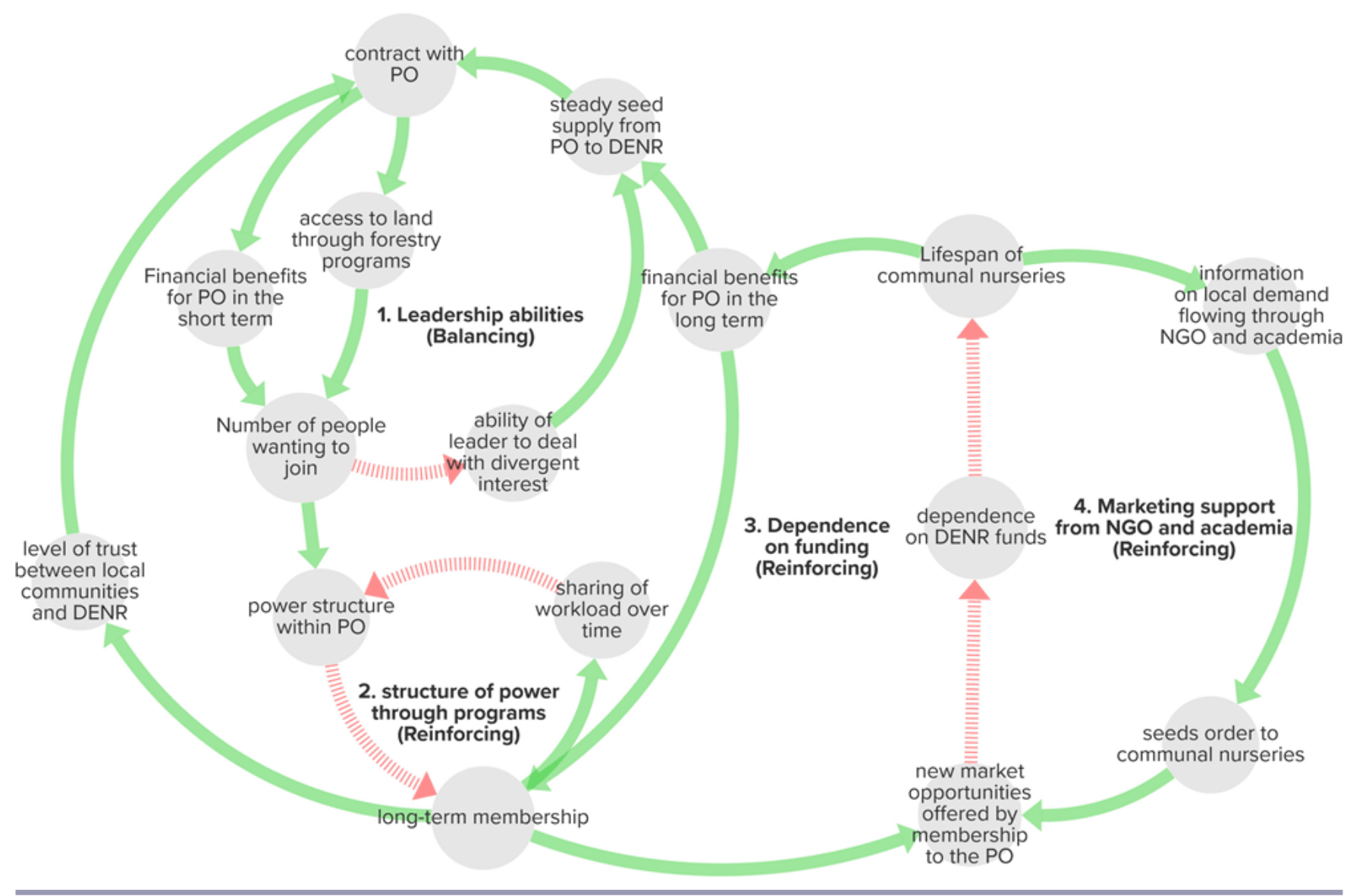

planting, but if the registration process for smallholders to participate in the formal wood supply sector proves to be difficult, smallholders may start to operate as timber buyers without official registration, which reduces the traceability of traded timber and fosters illegal logging.

\section{DISCUSSION}

The dynamic system approach enables a comprehensive overview of tree seed supply, integrating institutional, legislative, financial, social, ecological, and genetic aspects, and illustrating their complex interconnections. The resulting causal loop diagrams help gain clarity on unexpected or undesirable effects of interventions on the system. This approach is problem-oriented and aims to reflect and balance the perceptions and points of view of various stakeholders on shared issues. Two measures were taken to increase the robustness and relevance of the modeling: (i) using a framework of indicators to guide a systematic search of information (Atkinson et al. 2018), and (ii) involving diverse stakeholders in the interviews, to integrate different perspectives (Martinez-Moyano and Richardson 2013). Some feedback loops that reflected interactions between fine- and broad-scale dynamics were developed exclusively drawing on local-scale evidence (Peters et al. 2007). This enabled illustrating how national policies can influence seed production locally and how smallholders' characteristics and behavior can influence the implementation of national policies.

In Burkina Faso, while the National Tree Seed Center can deliver high-quality seeds for forest restoration initiatives, smallholders rely mostly on informal seed sources (Valette et al. 2019). Private nurseries had the potential to provide cheap planting material to smallholders in remote areas but faced many challenges including the lack of seed sources, inadequate seed collection guidelines, limited knowledge about nursery management, and scattered customers each purchasing only a few seedlings per species (Graudal and Lillesø 2007, Lillesø et al. 2011). Government institutions can contribute to creating an enabling environment for private nurseries through disseminating high-quality seeds through extension agents and generating demand for planting material through agroforestry or forest restoration programs (Nieuwenhuis and O'Connor 2000, Akinnifesi et al. 2006, Tchoundjeu et al. 2010, He et al. 2012, Lillesø et al. 2018). Official registration of private nurseries could benefit the smallholders 
involved, for example through fostering sharing of information among stakeholders in the seed supply chain. However, smallholders interested in planting trees and nursery owners are reluctant to formalize their activities because they are concerned about potential legal constraints, such as increased controls and taxes (Germano et al. 2007, Lua et al. 2015). This dynamic is similar to the shift to the burden system archetype, in which the Forest Department tends to focus more on controlling smallholders' actions rather than on establishing a collaborative relationship that would encourage compliance with the law. The situation could be improved if the Forest Department provided technical advice on nursery management and silviculture, ensured access to high-quality seed of native tree species for nursery owners, or subsidized smallholders in purchasing native tree seed. This dynamic could foster demand for high quality seed of native species (Meijer et al. 2015). The low rate of nursery registrations has been identified as a critical bottleneck also in several countries in Latin America (Atkinson et al. 2018). The authors recommended exploring options for consumer-driven approaches to motivate and expand nursery registration.

Mutual support between nursery owners can increase their commercial success and the quality of planting materials produced (Muriuki 2005, Catacutan et al. 2008). Through associations smallholders can more easily access economies of scale, achieve higher bargaining power, increase germplasm quality, and handle a greater diversity of tree species (Dawson et al. 2009, Markelova et al. 2009, Abizaid et al. 2016). The evolution of institutional arrangements whereby seedling producers are accountable for their own income-generating activities while supporting each other depends on their mutual trust and cooperation, which in turn are affected by the group size and the competitiveness in the tree nursery business (Poteete and Ostrom 2004). This reminds us that there are "limits to success" system archetype (Senge 1994). Evidence from agroforestry systems shows that dissemination of knowledge and seed among smallholders often follows a core-to-periphery structure: a core group of smallholders acquires knowledge from formal sources, exchanges advice, experiments, and disseminates knowledge to other smallholders (Isaac et al. 2007, Abizaid et al. 2016). This might also be a cost-efficient strategy to disseminate knowledge on tree planting and nursery management. Mentoring relationships between new and experienced nursery owners in a group of nursery owners can help maintain continued cooperation even as the number of nurseries grows.

In the Philippines, ambitious time-bound FLR targets combined with existing limitations in the seed supply system, especially for native tree species, have led to the implementation of a centralized approach to quickly build up a large seed supply, which resembles the "growth and underinvestment" and "fixes that fail" system archetypes (Senge 1994). The success of FLR initiatives is measured through survival rates of seedlings planted, which are often misreported by stakeholders to access state funds. By using only short-term seedling survival rates to measure success, longterm drivers of sustainable FLR initiatives, such as socioeconomic factors, are completely neglected (Le et al. 2012). The lack of reliable information on the effectiveness of FLR interventions prevents the Forest Department from identifying bottlenecks in the implementation of the eNGP and using corrective actions. One major implication of this is the persistent underfunding of capacity strengthening activities for smallholders on tree planting and nursery management, based on an assumption that previous capacity strengthening activities were successful. Delegating decision making about FLR initiatives to local administrative levels would enable adapting interventions to local contexts. Insights from community forestry programs indicate that fine-scale adaptation of rules and collegial decision making yield better results than centralized decision making and authoritarian implementation (Nayak and Berkes 2008, Persha and Blomley 2009, Cronkleton et al. 2012). Similarly to the findings from Burkina Faso, these results suggest that local forestry officers could play a much larger role in catalyzing and supporting smallholders' FLR efforts if they were given more resources, authority, or both.

In contrast to the nursery owners in central Burkina Faso, who self-organized to overcome business constraints in seed supply, smallholders in the Philippines were grouped in POs to facilitate distribution of state funds to them. However, government-led collective action implemented through formal or informal associations where decision-making power is unbalanced and whose members are influenced by external agents does not necessarily lead to cooperation and trust (de Vente et al. 2016, Reed et al. 2018). Moreover, donation of free seedlings by the DENR undermines market demand for seedlings, which limits the opportunities for PO nurseries to become independent of state support. These dynamics correspond to a "shift the burden" archetype (Senge 1994), as short-term availability of seedlings is prioritized over long-term development of the nursery sector. Interventions should focus on building stronger synergies between government-facilitated seed supply and operations of the POs. If seedling donations to smallholders are considered necessary to encourage tree planting, POs should be in charge of production, instead of government nurseries, and should be compensated for this by the DENR. This would allow bridging through government funding the gap between the market price of seedlings and smallholders' purchasing power, and POs could assume responsibility for upscaling the production of planting material and hence turn it into a sustainable business (Cornelius and Miccolis 2018). To support the development of the nursery sector, the government could also focus on strengthening the capacities of PO members in nursery management. Regular training sessions have proven successful in ensuring the adoption of best practices in nursery management (Böhringer and Ayuk 2003, Tchoundjeu et al. 2006, Roshetko et al. 2013).

In both countries, exotic tree species were preferred for tree planting because of their availability and productivity, resulting in higher income for smallholders and profit for the industrial sector (Abiyu et al. 2016, Iiyama et al. 2018). This in turn results in higher investment in developing silvicultural guidelines and improving planting material for exotic species at the expense of native species. Similar trends have been reported in Latin American countries (Atkinson et al. 2018). However, using exotic species in FLR brings limited biodiversity benefits, compared to native species (Bremer and Farley 2010). Wider use of native species in FLR could be effectively promoted by redirecting public funding toward improving demand for and supply of their planting material, especially as popular exotic trees often already benefit from private sector investment. Government nurseries could focus on producing planting material of lesser-known 
native species, establishing guidelines for planting and rotation cycles to increase productivity, demonstrating the potential of native species and fostering their use in FLR interventions and other planting initiatives (Graudal and Lillesø 2007, Garen et al. 2009). The production of such species could later be transferred to private nurseries that often lack the operational and financial means to invest in scaling. Atkinson et al. (2018) highlighted the need to compile and make widely available knowledge on the ecology and uses of native species, which is currently fragmented across various sources and stakeholders, from local communities to academia and different government departments. Because tree productivity and seed availability strongly influence smallholder planting preferences, improvements that address these aspects could favor the adoption and use of native tree species both by smallholders on their own lands and large-scale FLR initiatives (Assogbadjo et al. 2012, Ndayambaje et al. 2012, Sacande and Berrahmouni 2016).

Forest degradation and overexploitation often disproportionately target populations of the most valuable tree species (Pandit and Thapa 2003, Ndangalasi et al. 2007), leading to genetic erosion and the depletion of quality seed sources (Simons and Leakey 2004). Authoritarian solutions to avoid forest degradation through strict law enforcement have shown limited success in lower-income countries with persistent poverty and many forestdependent people (Jachmann 2008, Porter-Bolland et al. 2012). Potentially more effective solutions include reinforcing local institutions that regulate forest resource use or developing alternative livelihood opportunities, including small-scale nursery businesses (Meitzner Yoder 2007, Mukul et al. 2014, Pohnan et al. 2015). Such measures can promote collaboration in managing the remaining forest resources and create favorable conditions for the success of further FLR interventions (Uddin et al. 2007).

\section{CONCLUSION}

Our analysis of the tree seed supply systems in Burkina Faso and the Philippine shows that despite well-meant initiatives, such as introducing seedling quality standards, subsidizing seedling purchases, and involving community organizations, seed and seedling supply is not adequately meeting the demand for implementing FLR, neither in terms of quantity and quality nor the desired livelihood outcomes, in the contexts analyzed. Issues like those identified in the two case studies of Burkina Faso and the Philippines are likely to occur elsewhere in similar sociopolitical contexts. In Burkina Faso and the Philippines, the emerging options to strengthen supply systems for successful FLR include (i) a better tailoring of interventions to address the local context, including revisiting the role of local forestry officers; (ii) aligning government and NGO interventions to support existing nursery, tree planting, and research initiatives, rather than duplicating efforts or competing with them; and (iii) complementing the enforcement of regulations with strengthening the capacities of nurseries in producing high quality planting material and the capacities of local institutions in resource management to foster law compliance.

Responses to this article can be read online at: https://www.ecologyandsociety.org/issues/responses. php/12032

\section{Acknowledgments:}

This research has been conducted with the support of 12 anonymous collaborators who provided precious feedback on the causal loop diagrams developed and overall help in this work. The authors thank Olga Spellman (Bioversity International) for English editing and text revision. The authors would also like to thank the Austrian Development Agency for funding the project "Nutrition-sensitive forest restoration to enhance adaptive capacity of rural communities in Burkina Faso," which generated primary data for this study, the partners of the above-mentioned project for their fruitful collaboration, as well as the two anonymous reviewers for their valuable comments for improving the manuscript. This research contributes to the CGIAR Research Program on Forest Trees and Agroforestry and was supported by the CGIAR Fund donors, https:// www.cgiar.org/fundersl.

\section{Data Availability:}

Code sharing is not applicable to this article because no new code was created and data are shared within the appendices of the article. We worked jointly with a national partner and followed their ethical standards. We asked prior informed consent to the persons interviewed.

\section{LITERATURE CITED}

Abiyu, A., D. Teketay, G. Gratzer, and M. Shete. 2016. Tree planting by smallholder farmers in the Upper Catchment of Lake Tana Watershed, Northwest Ethiopia. Small-scale Forestry 15 (2):199-212. https://doi.org/10.1007/s11842-015-9317-7

Abizaid, C., O. T. Coomes, and M. Perrault-Archambault. 2016. Seed sharing in Amazonian Indigenous rain forest communities: a social network analysis in three Achuar Villages, Peru. Human Ecology 44(5):577-594. https://doi.org/10.1007/s10745-016-9852-7

Akinnifesi, F. K., F. Kwesiga, J. Mhango, T. Chilanga, A. Mkonda, C. A. C. Kadu, I. Kadzere, D. Mithofer, J. D. K. Saka, G. Sileshi, T. Ramadhani, and P. Dhliwayo. 2006. Towards the development of mionbo fruits trees as commercial tree crops in Southern Africa. Forests, Trees and Livelihoods 16(1):103-121. https://doi.org/10.1080/14728028.2006.9752548

Alexander, S., C. R. Nelson, J. Aronson, D. Lamb, A. Cliquet, K. L. Erwin, C. M. Finlayson, R. S. de Groot, J. A. Harris, E. S. Higgs, R. J. Hobbs, R. R. R. Lewis, D. Martinez, and C. Murcia. 2011. Opportunities and challenges for ecological restoration within REDD+. Restoration Ecology 19(6):683-689. https://doi. org/10.1111/j.1526-100X.2011.00822.X

Alfaro, R. I., B. Fady, G. G. Vendramin, I. K. Dawson, R. A. Fleming, C. Sáenz-Romero, R. A. Lindig-Cisneros, T. Murdock, B. Vinceti, C. M. Navarro, T. Skrøppa, G. Baldinelli, Y. A. ElKassaby, and J. Loo. 2014. The role of forest genetic resources in responding to biotic and abiotic factors in the context of anthropogenic climate change. Forest Ecology and Management 333:76-87. https://doi.org/10.1016/j.foreco.2014.04.006

Assogbadjo, A. E., R. Glèlè Kakaï, F. G. Vodouhê, C. A. M. S. Djagoun, J. T. C. Codjia, and B. Sinsin. 2012. Biodiversity and socioeconomic factors supporting farmers' choice of wild edible 
trees in the agroforestry systems of Benin (West Africa). Forest Policy and Economics 14(1):41-49. https://doi.org/10.1016/j. forpol.2011.07.013

Atkinson, R., E. Thomas, J. Cornelius, R. Zamora, and M. Franco Chuaire. 2018. Fit-for-purpose seed supply systems for the implementation of landscape restoration under Initiative 20x20: an analysis of national seed systems in Mexico, Guatemala, Costa Rica, Colombia, Peru, Chile and Argentina. World Resources Institute, Bioversity International, ICRAF, Lima, Peru.

Banson, K. E., N. C. Nguyen, and O. J. H. Bosch. 2016. Using system archetypes to identify drivers and barriers for sustainable agriculture in Africa: a case study in Ghana. Systems Research and Behavioral Science 33(1):79-99. https://doi.org/10.1002/ $\underline{\text { sres. } 2300}$

Biggs, S. 2007. Building on the positive: an actor innovation systems approach to finding and promoting pro poor natural resources institutional and technical innovations. International Journal of Agricultural Resources, Governance and Ecology 6 (2):144-164. https://doi.org/10.1504/IJARGE.2007.012701

Böhringer, A., and E. T. Ayuk. 2003. Farmer nurseries as a catalyst for developing sustainable land use systems in southern Africa. Part B: Support systems, early impact and policy issues. Agricultural Systems 77(3):203-217. https://doi.org/10.1016/ s0308-521x(02)00186-5

Brancalion, P. H. S., D. Schweizer, U. Gaudare, J. R. Mangueira, F. Lamonato, F. T. Farah, A. G. Nave, and R. R. Rodrigues. 2016. Balancing economic costs and ecological outcomes of passive and active restoration in agricultural landscapes: the case of Brazil. Biotropica 48(6):856-867. https://doi.org/10.1111/btp.12383

Bremer, L. L., and K. A. Farley. 2010. Does plantation forestry restore biodiversity or create green deserts? A synthesis of the effects of land-use transitions on plant species richness. Biodiversity and Conservation 19(14):3893-3915. https://doi. org/10.1007/s10531-010-9936-4

Broadhurst, L. M., T. A. Jones, F. S. Smith, T. North, and L. Guja. 2016. Maximizing seed resources for restoration in an uncertain future. BioScience 66(1):73-79. https://doi.org/10.1093/biosci/ $\underline{\text { biv155 }}$

Catacutan, D., M. Bertomeu, L. Arbes, C. Duque, and N. Butra. 2008. Fluctuating fortunes of a collective enterprise: the case of the Agroforestry Tree Seeds Association of Lantapan (ATSAL) in the Philippines. Small-scale Forestry 7(3-4):353-368. https:// doi.org/10.1007/s11842-008-9059-X

Chazdon, R. L., and M. R. Guariguata. 2016. Natural regeneration as a tool for large-scale forest restoration in the tropics: prospects and challenges. Biotropica 48(6):716-730. https://doi.org/10.1111/btp.12381

Ciccarese, L., A. Mattsson, and D. Pettenella. 2012. Ecosystem services from forest restoration: thinking ahead. New Forests 43 (5-6):543-560. https://doi.org/10.1007/s11056-012-9350-8

Cornelius, J. P., and A. Miccolis. 2018. Can market-based agroforestry germplasm supply systems meet the needs of forest landscape restoration? New Forests 49(4):457-469. https://doi. org/10.1007/s11056-018-9639-3
Cronkleton, P., J. Pulhin, and S. Saigal. 2012. Co-management in community forestry: how the partial devolution of management rights creates challenges for forest communities. Conservation and Society 10(2):91-102. https://doi.org/10.4103/0972-4923.97481

Dawson, I. K., A. Lengkeek, J. C. Weber, and R. Jamnadass. 2009. Managing genetic variation in tropical trees: linking knowledge with action in agroforestry ecosystems for improved conservation and enhanced livelihoods. Biodiversity and Conservation 18:969. https://doi.org/10.1007/s10531-008-9516-Z

de Urzedo, D. I., R. Fisher, F. C. M. Piña-Rodrigues, J. M. Freire, and R. G. P. Junqueira. 2019. How policies constrain native seed supply for restoration in Brazil. Restoration Ecology 4 (27):768-774. https://doi.org/10.1111/rec.12936

De Vente, J., M. S. Reed, L. C. Stringer, S. Valente, and J. Newig. 2016. How does the context and design of participatory decision making processes affect their outcomes? Evidence from sustainable land management in global drylands. Ecology and Society 21(2):24. https://doi.org/10.5751/ES-08053-210224

Department of Environment and Natural Resources (DENR). 2015. Executive Order no 193 series of 2015. Government of the Philippines, Manila, Philippines.

Doyle, J. K., and D. N. Ford. 1998. Mental models concepts for system dynamics research. System Dynamics Review 14(1):3-29. https://doi.org/10.1002/(SICI)1099-1727(199821)14:1<3::AID$\underline{\text { SDR } 140>3.0 . C O ; 2-K}$

Forrester, J. W. 1971. Counterintuitive behaviour of social systems. Technology Review 73(3):52-68.

Garen, E. J., K. Saltonstall, J. L. Slusser, S. Mathias, M. S. Ashton, and J. S. Hall. 2009. An evaluation of farmers' experiences planting native trees in rural Panama: implications for reforestation with native species in agricultural landscapes. Agroforestry Systems 76:219-236.

Germano, E. M., E. G. Tan, and E. Cedamon. 2007. Assessment of tree registration in Leyte and Biliran Islands. Annals of Tropical Research 29(3):40-48. https://doi.org/10.32945/atr2934.2007

Grainger, A., and B. S. Malayang. 2006. A model of policy changes to secure sustainable forest management and control of deforestation in the Philippines. Forest Policy and Economics 8 (1):67-80. https://doi.org/10.1016/j.forpol.2004.05.005

Graudal, L., and J. P. B. Lillesø. 2007. Experiences and future prospects for tree seed supply in agricultural developement support: based on lessons learnt in Danida supported programmes 1965-2005. Ministry of Foreign Affairs, Copenhagen, Denmark.

Gregorio, N., J. Herbohn, S. Harrison, A. Pasa, and A. Ferraren. 2017. Regulating the quality of seedlings for forest restoration: lessons from the National Greening Program in the Philippines. Small-scale Forestry 16(1):83-102. https://doi.org/10.1007/ s11842-016-9344-Z

He, J., H. Yang, R. Jamnadass, J. Xu, and Y. Yang. 2012. Decentralization of tree seedling supply systems for afforestation in the west of Yunnan Province, China. Small-scale Forestry 11 (2):147-166. https://doi.org/10.1007/s11842-011-9176-9 
Hirsch, G. B., R. Levine, and R. L. Miller. 2007. Using system dynamics modeling to understand the impact of social change initiatives. American Journal of Community Psychology 39 (3-4):239-253. https://doi.org/10.1007/s10464-007-9114-3

Hjorth, P., and A. Bagheri. 2006. Navigating towards sustainable development: a system dynamics approach. Futures 38(1):74-92. https://doi.org/10.1016/j.futures.2005.04.005

Iiyama, M., A. Mukuralinda, J. D. Ndayambaje, B. S. Musana, A. Ndoli, J. G. Mowo, D. Garrity, S. Ling, and V. Ruganzu. 2018. Addressing the paradox - the divergence between smallholders' preference and actual adoption of agricultural innovations. International Journal of Agricultural Sustainability 16(6):472-485. https://doi.org/10.1080/14735903.2018.1539384

Isaac, M. E., B. H. Erickson, S. Quashie-Sam, and V. R. Timmer. 2007. Transfer of knowledge on agroforestry management practices: the structure of farmer advice networks. Ecology and Society 12(2):32. https://doi.org/10.5751/ES-02196-120232

Jachmann, H. 2008. Monitoring law-enforcement performance in nine protected areas in Ghana. Biological Conservation 141 (1):89-99. https://doi.org/10.1016/j.biocon.2007.09.012

Jalonen, R., M. Valette, D. Boshier, J. Duminil, and E. Thomas. 2018. Forest and landscape restoration severely constrained by a lack of attention to the quantity and quality of tree seed: insights from a global survey. Conservation Letters 11(4):e12424. https:// doi.org/10.1111/conl.12424

Le, H. D., C. Smith, J. Herbohn, and S. Harrison. 2012. More than just trees: assessing reforestation success in tropical developing countries. Journal of Rural Studies 28(1):5-19. https:// doi.org/10.1016/j.jrurstud.2011.07.006

Lillesø, J. B. L., L. Graudal, S. Moestrup, E. D. Kjær, R. Kindt, A. Mbora, I. Dawson, J. Muriuki, A. Ræbild, and R. Jamnadass. 2011. Innovation in input supply systems in smallholder agroforestry: seed sources, supply chains and support systems. Agroforestry Systems 83(3):347-359. https://doi.org/10.1007/ $\underline{\text { s10457-011-9412-5 }}$

Lillesø, J. P. B., C. Harwood, A. Derero, L. Graudal, J. M. Roshetko, R. Kindt, S. Moestrup, W. O. Omondi, N. Holtne, A. Mbora, P. van Breugel, I. K. Dawson, R. Jamnadass, and H. Egelyng. 2018. Why institutional environments for agroforestry seed systems matter. Development Policy Review 36:89-112. https://doi.org/10.1111/dpr.12233

Liu, J., T. Dietz, S. R. Carpenter, M. Alberti, C. Folke, E. Moran, A. N. Pell, P. Deadman, T. Kratz, J. Lubchenco, E. Ostrom, Z. Ouyang, W. Provencher, C. L. Redman, S. H. Schneider, and W. W. Taylor. 2007. Complexity of coupled human and natural systems. Science 317(5844):1513-1516. https://doi.org/10.1126/ science. 1144004

Lua, H. T., J. M. Roshetko, D. Catacutan, and L. D. Thinh. 2015. A review of policy constraints and opportunities for the sustainable delivery of quality fruit tree germplasm in Vietnam. International Journal of Agriculture Innovations and Research 4 (3):536-543.

Markelova, H., R. Meinzen-Dick, J. Hellin, and S. Dohrn. 2009. Collective action for smallholder market access. Food Policy 34 (1):1-7. https://doi.org/10.1016/j.foodpol.2008.10.001
Martinez-Moyano, I. J., and G. P. Richardson. 2013. Best practices in system dynamics modeling. System Dynamics Review 29(2):102-123. https://doi.org/10.1002/sdr.1495

Meijer, S. S., D. Catacutan, G. W. Sileshi, and M. Nieuwenhuis. 2015. Tree planting by smallholder farmers in Malawi: using the theory of planned behaviour to examine the relationship between attitudes and behaviour. Journal of Environmental Psychology 43:1-12. https://doi.org/10.1016/j.jenvp.2015.05.008

Meitzner Yoder, L. S. 2007. Hybridising justice: state-customary interactions over forest crime and punishment in Oecusse, East Timor. Asia Pacific Journal of Anthropology 8(1):43-57. https:// doi.org/10.1080/14442210601161732

Ministeres de l'Environnement, de l'Economie Verte et du Changement Climatique (MEEVCC). 2010. Aide Mémoire Mission Préparation du PIF Burkina Faso. Government of Burkino Faso, Ouagadougou, Burkino Faso.

Mukul, S. A., J. Herbohn, A. Z. M. M. Rashid, and M. B. Uddin. 2014. Comparing the effectiveness of forest law enforcement and economic incentives to prevent illegal logging in Bangladesh. International Forestry Review 16(3):363-375. https://doi. org/10.1505/146554814812572485

Muriuki, K. J. 2005. Informal agroforestry tree seed quality and supply systems: a case of peri-urban Nairobi, Meru, and western Kenya. Thesis. Kenyatta University, Nairobi, Kenya.

Nayak, P. K., and F. Berkes. 2008. Politics of co-optation: community forest management versus joint forest management in Orissa, India. Environmental Management 41(5):707-718. https://doi.org/10.1007/s00267-008-9088-4

Ndangalasi, H. J., R. Bitariho, and D. B. K. Dovie. 2007. Harvesting of non-timber forest products and implications for conservation in two montane forests of East Africa. Biological Conservation 134:242-250. https://doi.org/10.1016/j.biocon.2006.06.020

Ndayambaje, J. D., W. J. M. Heijman, and G. M. J. Mohren. 2012. Household determinants of tree planting on farms in rural Rwanda. Small-scale Forestry 11(4):477-508. https://doi. org/10.1007/s11842-012-9196-0

Nicholson, C. F., B. Kopainsky, E. C. Stephens, D. Parsons, A. D. Jones, J. Garrett, and E. L. Phillips. 2020. Conceptual frameworks linking agriculture and food security. Nature Food 1 (9):541-551 https://doi.org/10.1038/s43016-020-00142-3

Nieuwenhuis, M., and N. O'Connor. 2000. Challenges and opportunities for small-scale tree nurseries in the East African highlands. Unasylva 51:56-60.

Nyoka, B. I., J. M. Roshetko, R. Jamnadass, J. Muriuki, A. Kalinganire, J.-P. B. Lillesø, T. Beedy, and J. Cornelius. 2015. Tree seeds and seedling supply systems: a review of the Asia, Africa and Latin America models. Small-scale Forestry(14):171-191. https://doi.org/10.1007/s11842-014-9280-8

Pandit, B. H., and G. B. Thapa. 2003. A tragedy of non-timber forest resources in the mountain commons of Nepal. Environmental Conservation 30(3):283-292. https://doi.org/10.1017/ $\underline{\mathrm{S} 0376892903000286}$ 
Persha, L., and T. Blomley. 2009. Management decentralization and montane forest conditions in Tanzania. Conservation Biology 23(6):1485-1496. https://doi.org/10.1111/j.1523-1739.2009.01276. $\underline{x}$

Peters, D. P. C., B. T. Bestelmeyer, and M. G. Turner. 2007. Crossscale interactions and changing pattern-process relationships: consequences for system dynamics. Ecosystems 10(5):790-796. https://doi.org/10.1007/s10021-007-9055-6

Pistorius, T., and H. Freiberg. 2014. From target to implementation: perspectives for the international governance of forest landscape restoration. Forests 5(3):482-497. https://doi. org/10.3390/f5030482

Pohnan, E., H. Ompusunggu, and C. Webb. 2015. Does tree planting change minds? Assessing the use of community participation in reforestation to address illegal logging in West Kalimantan. Tropical Conservation Science 8(1):45-57. https:// doi.org/10.1177/194008291500800107

Portela, R., and I. Rademacher. 2001. A dynamic model of patterns of deforestation and their effect on the ability of the Brazilian Amazonia to provide ecosystem services. Ecological Modelling 143:115-146. https://doi.org/10.1016/S0304-3800(01) 00359-3

Porter-Bolland, L., E. A. Ellis, M. R. Guariguata, I. Ruiz-Mallén, S. Negrete-Yankelevich, and V. Reyes-García. 2012. Community managed forests and forest protected areas: an assessment of their conservation effectiveness across the tropics. Forest Ecology and Management 268:6-17. https://doi.org/10.1016/j.foreco.2011.05.034

Poteete, A. R., and E. Ostrom. 2004. Heterogeneity, group size and collective action: the role of institutions in forest management. Development and Change 35(3):435-461. https://doi. org/10.1111/j.1467-7660.2004.00360.x

Reed, M. S., S. Vella, E. Challies, J. de Vente, L. Frewer, D. Hohenwallner-Ries, T. Huber, R. K. Neumann, E. A. Oughton, J. Sidoli del Ceno, and H. van Delden. 2018. A theory of participation: what makes stakeholder and public engagement in environmental management work? Restoration Ecology 26:S7S17. https://doi.org/10.1111/rec.12541

Reinker, M., and E. Gralla. 2018. A system dynamics model of the adoption of improved agricultural inputs in Uganda, with insights for systems approaches to development. Systems 6(3):31. https://doi.org/10.3390/systems6030031

Roshetko, J. M., I. K. Dawson, J. Urquiola, R. D. Lasco, B. Leimona, J. C. Weber, M. Bozzano, J.-P. B. Lillesø, L. Graudal, and R. Jamnadass. 2018. To what extent are genetic resources considered in environmental service provision? A case study based on trees and carbon sequestration. Climate and Development 10 (8):755-768. https://doi.org/10.1080/17565529.2017.1334620

Roshetko, J. M., N. Idris, P. Purnomosidhi, T. Zulfadhli, and J. Tarigan. 2013. Farmer extension approach to rehabilitate smallholder fruit agroforestery systems: the "Nurseries Of Excellence (NOEL)" program in Aceh, Indonesia. Acta Horticulturae (975):649-656. https://doi.org/10.17660/ actahortic.2013.975.81

Roshetko, J. M., Mulawarman, and A. Dianarto. 2008. Tree seed procurement-diffusion pathways in Wonogiri and Ponorogo,
Java. Small-scale Forestry 7(3-4):333-352. https://doi.org/10.1007/ s11842-008-9058-y

Sacande, M., and N. Berrahmouni. 2016. Community participation and ecological criteria for selecting species and restoring natural capital with native species in the Sahel. Restoration Ecology 24(4):479-488. https://doi.org/10.1111/ rec. 12337

Sahin, O., R. A. Stewart, and M. G. Porter. 2015. Water security through scarcity pricing and reverse osmosis: a system dynamics approach. Journal of Cleaner Production 88:160-171. https://doi. org/10.1016/j.jclepro.2014.05.009

Senge, P. M. 1994. The fifth discipline: the art and practice of the learning organization. Currency Doubleday, New York, New York, USA.

Shono, K., E. A. Cadaweng, and P. B. Durst. 2007. Application of assisted natural regeneration to restore degraded tropical forestlands. Restoration Ecology 15(4):620-626. https://doi. org/10.1111/j.1526-100X.2007.00274.X

Simons, A. J., and R. R. B. Leakey. 2004. Tree domestication in tropical agroforestry. Agroforestry Systems 61:167-181. https:// doi.org/10.1023/b:agfo.0000028997.74147.f9

Tchoundjeu, Z., E. K. Asaah, P. Anegbeh, A. Degrande, P. Mbile, C. Facheux, A. Tsobeng, A. R. Atangana, M. L. Ngo-Mpeck, and A. J. Simons. 2006. Putting participatory domestication into practice in West and Central Africa. Forests, Trees and Livelihoods 16(1):53-69. https://doi.org/10.1080/14728028.2006.9752545

Tchoundjeu, Z., A. Degrande, R. R. B. Leakey, G. Nimino, E. Kemajou, E. Asaah, C. Facheux, P. Mbile, C. Mbosso, T. Sado, and A. Tsobeng. 2010. Impacts of participatory tree domestication on farmer livelihoods in West and Central Africa. Forests, Trees and Livelihoods 19(3):217-234. https://doi. org/10.1080/14728028.2010.9752668

Thomas, E., R. Jalonen, J. Loo, D. Boshier, L. Gallo, S. Cavers, S. Bordács, P. Smith, and M. Bozzano. 2014. Genetic considerations in ecosystem restoration using native tree species. Forest Ecology and Management 333:66-75. https://doi. org/10.1016/j.foreco.2014.07.015

Uddin, M. S., S. A. Mukul, M. A. S. Arfin, C. A. A. Asif, and M. Alamgir. 2007. Comparative evaluation of co-management impacts in protected area: a case study from Lawachra National Park of Maulvibazar, Sylhet. Journal of Forestry and Environment 5:103-110.

Valette, M., B. Vinceti, D. Traoré, A. T. Traoré, E. L. YagoOuattara, and F. Kaguembèga-Müller. 2019. How diverse is tree planting in the central plateau of Burkina Faso? Comparing small-scale restoration with other planting initiatives. Forests 10 (3):227. https://doi.org/10.3390/f10030227

Wolstenholme, E. F. 2003. Towards the definition and use of a core set of archetypal structures in system dynamics. System Dynamics Review 19(1):7-26. https://doi.org/10.1002/sdr.259

Zexian, Y., and Y. Xuhui. 2010. A revolution in the field of systems thinking-a review of Checkland's system thinking. Systems Research and Behavioral Science 27(2):140-155. https://doi. org/10.1002/sres. 1021 


\section{Appendix 1}

Table A1.1. List of the indicators used to define dynamics system's boundary, adapted from Atkinson et al. 2018. Indicators marked with an asterisk $\left({ }^{*}\right)$ have been added or modified from the original versions.

\begin{tabular}{|c|c|}
\hline Categories & Indicators \\
\hline $\begin{array}{l}\text { I. Selection and } \\
\text { innovation }\end{array}$ & $\begin{array}{l}\text { 1. Different sources of information are used to identify native species useful for restoration in } \\
\text { a variety of ecosystems } \\
\text { 2. Research into the effect of climate change on native species across different ecosystems is } \\
\text { used to inform species selection and seed sourcing for restoration } \\
\text { 3. Results from a network of provenance trials across the country is used to identify suitable } \\
\text { seed sources for restoration } \\
\text { 4. Research into the genetic characterization of species and ecogeographical zones is used to } \\
\text { define seed transfer zones } \\
\text { 5. Improved material is being developed for priority species used in production restoration } \\
\text { 6. Suitable information is readily available to inform stakeholders' restoration choices }\end{array}$ \\
\hline $\begin{array}{l}\text { II. Seed harvesting and } \\
\text { production }\end{array}$ & $\begin{array}{l}\text { 7. Seed sources that cover the geographical range of the priority native species have been } \\
\text { identified and are protected effectively } \\
\text { 8. Improved material is available for those priority species used in production restoration } \\
\text { 9. Nurseries are able to produce the priority species adapted to each ecosystem } \\
\text { 10. Incomes are generated for the local communities, though production of planting material, } \\
\text { and are equitably shared between social groups* }\end{array}$ \\
\hline $\begin{array}{l}\text { III. Market access, } \\
\text { supply and demand }\end{array}$ & $\begin{array}{l}\text { 11. There is demand for priority native species of suitable provenance for restoration across } \\
\text { targeted ecosystems, including by the smallholders } \\
\text { 12. There is a network of suppliers able to meet the demand for priority native species of } \\
\text { suitable provenance across targeted ecosystems } \\
\text { 13. There is a steady demand for seeds, which is unlikely to decrease in the near future * }\end{array}$ \\
\hline $\begin{array}{l}\text { IV. Quality control } \\
\overline{\text { V. Enabling }} \\
\text { environment }\end{array}$ & $\begin{array}{l}\text { 14. There is a certification system for seed quality for restoration planting } \\
\text { species, and is implemented } \\
\text { 16. Seed collectors are able to access appropriate seed sources, technical and market } \\
\text { knowledge and material to engage in seed collection, production and/or delivery* } \\
\text { 17. There is appropriate capacity building to support a thriving seed system } \\
\text { 18. There is sufficient long-term financial support for key research needed to support the seed } \\
\text { system } \\
\text { 19. There is a platform allowing experience sharing and capitalization of past success/failures } \\
\text { stories for the forest landscape restoration stakeholders* } \\
\text { 20. Publicly funded and project-based investments in seed supply are aimed at strengthening } \\
\text { existing supply systems rather than building parallel, competing and temporary supply } \\
\text { sources* }\end{array}$ \\
\hline
\end{tabular}




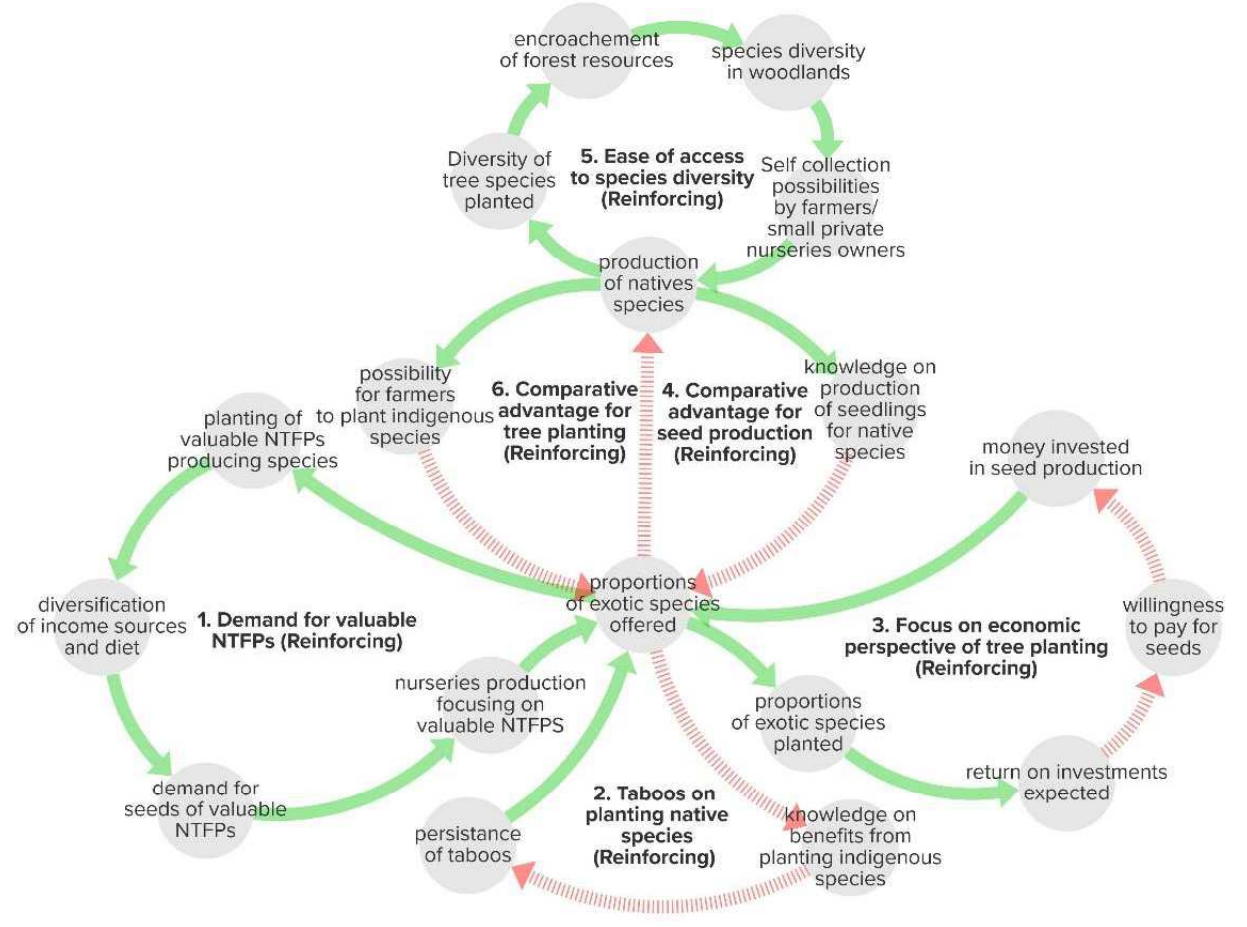

Figure A1.1: Causal loop diagram of the dynamic affecting the choice of the species planted by the smallholders in the case of Burkina Faso. The labels in bold indicate the names of the feedback loops. The continuous green arrows correspond to the similar relationship between variables (when one variable increases, so does the other), and the red dashed arrows correspond to inverse relationship (when one variable increases, the other decreases). Some elements have been excluded from the figure for clarity. The complete map is presented in https://embed.kumu.io/b260c9f20c884628a62096891f8a657e, and explanations of feedback loops are included in Appendix 3. 


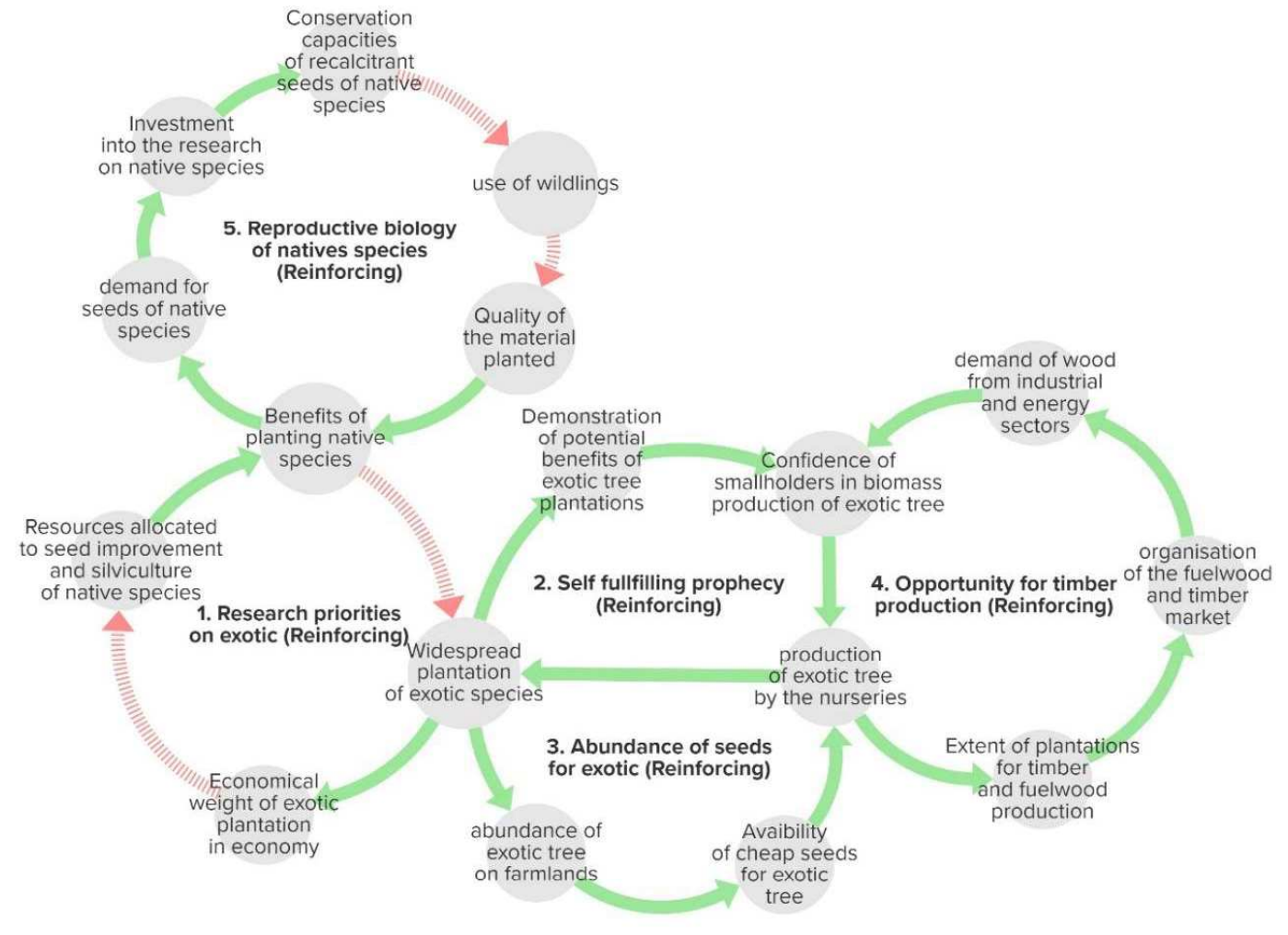

Figure A1.2: Causal loop diagram of the dynamic affecting the choice of the species planted by the smallholders in the case of the Philippines. The labels in bold indicate the names of the feedback loops. The continuous green arrows correspond to the similar relationship between variables (when one variable increases, so does the other), and the red dashed arrows correspond to inverse relationship (when one variable increases, the other decreases). Some elements have been excluded from the figure for clarity. The complete map is presented in https:/embed.kumu.io/5fb9a2720dd3698a4eb66315341eaaee, and explanations of feedback loops are included in Appendix 3. 


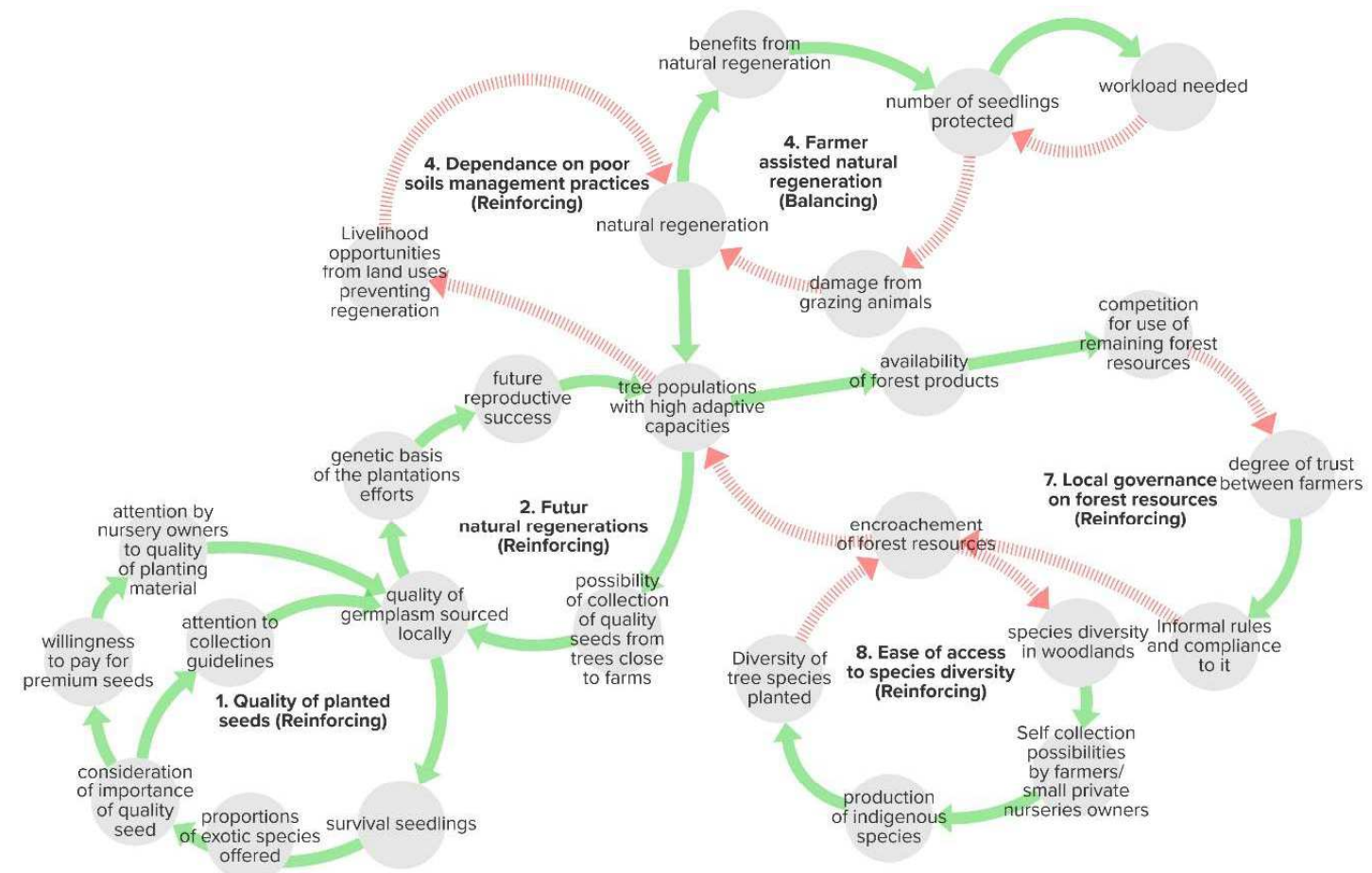

Figure A1.3: Causal loop diagram of the dynamic affecting the conservation of remaining forest in the case of Burkina Faso. The labels in bold indicate the names of the feedback loops. The continuous green arrows correspond to the similar relationship between variables (when one variable increases, so does the other), and the red dashed arrows correspond to inverse relationship (when one variable increases, the other decreases). Some elements have been excluded from the figure for clarity. The complete map is presented in https:/embed.kumu.io/b260c9f20c884628a62096891f8a657e, and explanations of feedback loops are included in Appendix 3. 


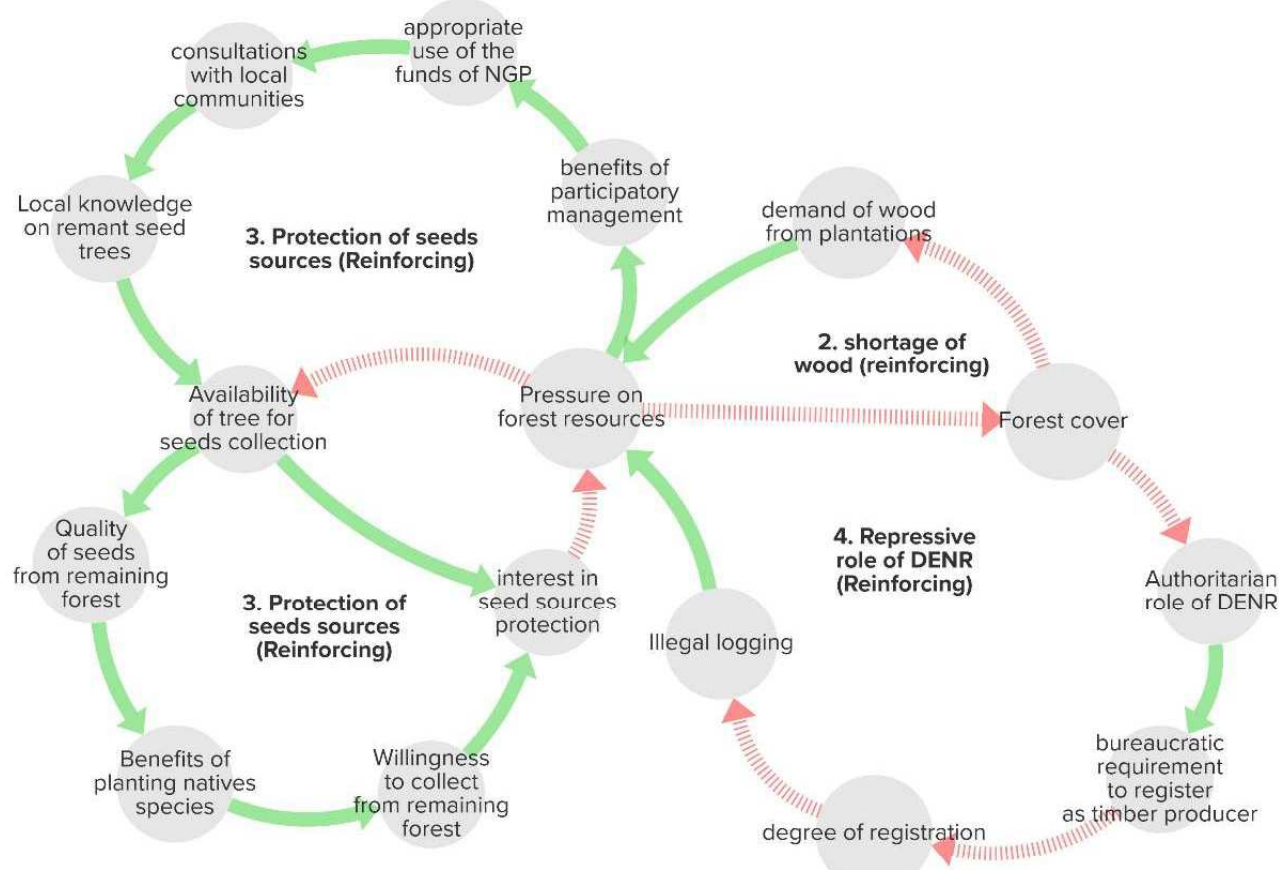

Figure A1.4: Causal loop diagram of the dynamic affecting the conservation of remaining forest in the case of the Philippines. The labels in bold indicate the names of the feedback loops. The continuous green arrows correspond to the similar relationship between variables (when one variable increases, so does the other), and the red dashed arrows correspond to inverse relationship (when one variable increases, the other decreases). Some elements have been excluded from the figure for clarity. The complete map is presented in https://embed.kumu.io/5fb9a2720dd3698a4eb66315341eaaee, and explanations of feedback loops are included in Appendix 


\section{Appendix 2}

Table A2.1. Summary of the dynamics captured in the causal loop diagrams by thematic section, with key literature used to identify them. Identified system archetypes are shown in bold (Braun, 2002; Table 2).

\begin{tabular}{|c|c|}
\hline Thematic sections & Descriptions \\
\hline \multicolumn{2}{|r|}{ Burkina Faso } \\
\hline $\begin{array}{l}\text { 1. Centralized seed } \\
\text { production }(6 \text { feedback } \\
\text { loops) }\end{array}$ & $\begin{array}{l}\text { The production and distribution of seeds by the National Tree Seed Centre of Burkina Faso (CNSF) is expensive due to poor road infrastructure. This reduces seed sales and } \\
\text { potential clients may refer to other seed sources of poorer quality. Consequently, CNSF tends to focus on a partnership with the Forest Department to increase its share in the } \\
\text { national seed market for restoration projects led by the government. In some cases, this has negative effects on the relationship between CNSF and other implementers of } \\
\text { restoration projects, who see CNSF taking a sort of monopoly of the seeds market, imposing high seed prices (shifting the burden). However, if a collaboration is established } \\
\text { between project implementers and CNSF, this can lead to benefits for both sides and to positive outcomes that are likely to encourage practitioners to seek scientific support from } \\
\text { CNSF in future forest landscape restoration (FLR) initiatives and to make use of good quality germplasm (Graudal 1998). }\end{array}$ \\
\hline $\begin{array}{l}\text { 2. Short-term project } \\
\text { funding (4 feedback } \\
\text { loops) }\end{array}$ & $\begin{array}{l}\text { The dependence on short-term funding for FLR creates disincentives for establishing an effective monitoring system for forest landscape restoration success (growth and } \\
\text { underinvestment), leading to a lack of attention to seed quality in FLR efforts. Underfunding also leads to competition between stakeholders involved in FLR for funds } \\
\text { (escalation) and a weak consultation of local communities (Bouda et al. 2011). }\end{array}$ \\
\hline $\begin{array}{l}\text { 3. Approach of the } \\
\text { Forest Department ( } 4 \\
\text { feedback loops) }\end{array}$ & $\begin{array}{l}\text { Forest officers prioritize focusing their limited resources in enforcing laws that prevent overharvesting over supporting smallholders in seed production and providing silvicultural } \\
\text { advice. This results in limited collaboration between smallholders and forest officers and may lead to illegal cutting (shifting the burden). This limited collaboration from forest } \\
\text { officers, associated with the administrative burden involved in formalizing the production of nurseries managed by smallholders, discourage official registration of nurseries and } \\
\text { makes it difficult to enforce seed collection guidelines (Bassirou 2008, Vallino 2009, Coulibaly-Lingani et al. 2011, Bouda et al. 2011, Tankoano et al. 2015). }\end{array}$ \\
\hline $\begin{array}{l}\text { 4. Fair Benefit Sharing } \\
\text { (3 feedback loops) }\end{array}$ & $\begin{array}{l}\text { When illegal logging occurs, lack of trust between smallholders weakens the social capital, which in turn may create competition for remaining forest resources (tragedy of the } \\
\text { commons) and favor the monopolization of forest resources by a few individuals in a position of power, undermining the potential for future collective actions (Coulibaly-Lingani } \\
\text { et al. 2011, Bouda et al. 2011, Westholm and Arora-Jonsson 2015). }\end{array}$ \\
\hline $\begin{array}{l}\text { 5. Civil society support } \\
\text { to tree planters }(6 \\
\text { feedbacks loops) }\end{array}$ & $\begin{array}{l}\text { The civil society often supports local smallholders in planting trees and, when benefits and awareness start materializing, the example is followed by other smallholders. The civil } \\
\text { society can also support local seedling producers by providing resources for training. On the other hand, free distribution of seedlings by the civil society to smallholder farmers is } \\
\text { likely to undermine market opportunities for local nurseries, unless seedlings are bought from local nurseries (fixes that fail, Raebild et al. 2004). }\end{array}$ \\
\hline $\begin{array}{l}\text { 6. Farmers' nursery } \\
\text { networks (4 feedback } \\
\text { loops) }\end{array}$ & $\begin{array}{l}\text { When local demand for planting material increases, so does the number of seedling producers. If there is a good degree of cooperation (limits to success), seedling producers can } \\
\text { form a network in which they can share information on nursery techniques and location of tree seed sources, supporting each other in meeting seed demand of particular tree } \\
\text { species, and improving opportunities to respond to local and regional demands while reducing operating costs. }\end{array}$ \\
\hline $\begin{array}{l}\text { 7. Preferences for } \\
\text { exotic species }(4 \\
\text { feedback loops) }\end{array}$ & $\begin{array}{l}\text { Cultural taboos and low profitability hinder planting of native tree species, shifting the focus of smallholders towards planting exotic tree species that generate higher incomes } \\
\text { (success to successful, Raebild et al. 2004, Etongo et al. 2015). }\end{array}$ \\
\hline $\begin{array}{l}\text { 8. Forest protection or } \\
\text { further degradation ( } 5 \\
\text { feedback loops) }\end{array}$ & $\begin{array}{l}\text { In a context characterized by a reduction in forest cover, assisted natural regeneration interventions and regulations on the use of forest resources have been implemented in some } \\
\text { areas of Burkina Faso to promote a more effective protection of forest resources and encourage stakeholders' interest in sustainable forest management. In other parts of the } \\
\text { country, competition for the remaining forest resources is increasing and soil is degraded, limiting natural regeneration and leading to further environmental damage (tragedy of } \\
\text { the commons, Gijsbers et al. 1994, Raebild et al. 2004, Bayala et al. 2011, Savadogo et al. 2012, Schumann et al. 2012, Thiombiano et al. 2013). }\end{array}$ \\
\hline
\end{tabular}


9. Conservation of genetic resources (3 feedback loops)

1. Effectiveness of the Department of

Environment and

Natural Resources

(DENR) (5 feedback loops)

2. Conservation of the seed sources (3

feedback loops)

3. Private nurseries ( 3 feedback loops)

4. Sustainability of People's Organization (PO) (5 feedback loops)

5. Predominance of exotic species in tree planting (5 feedback loops)

6. Regional nurserie (3 feedback loops)

7. Mismatch of funding and goals (6 feedback loops)

8. Local knowledge transfer (3 feedback loops)
Planting high-quality seeds, adapted to the current and expected future conditions at a planting site, combined with natural regeneration, enhances the chances of tree survival and recovery of the forest ecosystem. The use of good quality seed is important to optimize survival rates and growth performance, increasing the interest of smallholders in using high quality seed and encouraging seedling producers in adopting best practices for seed collection (Broadhurst et al. 2006).

\section{The Philippines}

Only a few smallholders producing timber and/or providing forest planting material are officially registered with the Department of Environment and Natural Resources (DENR), which reduces the capacity of DENR to support and cooperate with a broad range of this kind of players in the seed system. This leads to reduced effectiveness of capacity strengthening of smallholders in seed supply, and their ability to produce seedlings for the enhanced National Greening Program (eNGP, growth and underinvestment). The lack of funding available to DENR officers could motivate them to make local communities pay for services that should be free, such as their registration as official timber producers. Such actions can further reduce trust between DENR and local communities. This disconnect between DENR and smallholders feeds a negative loop and disincentivizes producers to register their business with DENR (Gregorio et al. 2004, 2015, Dahal and Capistrano 2006, Germano et al. 2007, Pulhin et al. 2007, Baynes and Gregorio 2008, Catacutan et al. 2008, Harrison et al. 2008, Mercado and Duque-Piñon 2008, Russell et al. 2011, Baynes et al. 2011, 2016)

The demand for industrial wood is greater than the supply, and pressure increases on the remaining forest resources (tragedy of the commons). Populations of highly valuable trees are reduced to the point that it is difficult to find good quality seed sources. Thus, planting such tree species becomes more expensive and planting material could be of lowe quality, making their cultivation less profitable for smallholders (Gregorio et al. 2004, 2011b, Carandang et al. 2006, Bensel 2008, Gravoso et al. 2011, Santos Martín et al. 2012, Le et al. 2014, Peque and Hölscher 2014, Baynes et al. 2016).

Private nurseries generally have the capacity to respond to increases in local demand for trees and seedlings. However, their success may be constrained by the existence of regional public nurseries that compete with them, creating unfavourable market conditions (fixes that fails, Carandang et al. 2006, Mercado and Duque-Piñon 2008, Gregorio et al. 2010).

The opportunities offered by contracts between DENR and POs - groups of smallholders implementing forest activities defined by DENR - initially attracted many people to join POs. However, over time, the increasingly large size of the POs created a need for strong leadership, without which the long-term operationality of POs was put under pressure (limits to success). Moreover, irregular funding and lack of alternative income opportunities drove many PO members to drop out (shifting the burden). As a result, a few remaining powerful members currently dominate the POs, concentrating power and benefits and engaging other smallholders only as workforce (fixes that fail). A diversified access to customers, other than government agencies, to sell seedlings is a way to secure long-term funding and operability of the POs, but this means a good level of cooperatio needs to be in place for the POs to function well and adequately respond to demand for seed (success to successful, Catacutan and Mercado 2001, Bertomeu 2002, Dahal and Capistrano 2006, Pulhin et al. 2007, Catacutan et al. 2008, Harrison et al. 2008, Edralin and Mercado 2010, Gregorio et al. 2010, 2011b, Baynes et al. 2015, Gregorio et al. 2017). The main motivation for tree planting is timber production, so smallholders tend to choose fast-growing exotic tree species that have been widely planted in past restoration projects and, hence, have abundant seed sources and available silvicultural knowledge (success to the successful). By contrast, native tree species have largely been neglected by research efforts. Furthermore, the reproductive biology of some native tree species (e.g. masting) constrains seed collection and leads to increased use of wildlings, which often perform poorly when transplanted, due to damage to the root system during collection (Emtage and Suh 2004, Gregorio et al. 2004, 2011a, 2012, Carandang et al. 2006, Bernaldez and Mangaoang 2008, Santos Martín et al. 2012, Schneider et al. 2014, Nguyen et al. 2014).

Central nurseries have been established to address the need for high-quality planting material. However, high costs, seedling mortality related to transportation, and the availability of tree seed for a very limited range of tree species, makes this centralized model inefficient in responding to the demands of smallholders (fixes that fails, Gregorio et al. 2008 , 2011b, Kadda et al. 2008, Mercado et al. 2010).

Ambitious reforestation plans are being implemented in the Philippines to counter deforestation and forest degradation. However, the ambitious goals are not supported by adequate funding on a per hectare basis; thus, regulations on seed quality are difficult to implement effectively (growth and underinvestment). Furthermore, monitoring systems tend to focus on short-term indicators and encourage fraudulent reporting, because funds are only released when an $85 \%$ survival rate is reached. Limited success reinforces the tendency for central control, exacerbating miscommunication with the local government units (fixes that fail). This leads to a lack of consultation with local communities, delays in funding and inappropriate approaches to strengthen local capacities and institutions (growths and underinvestment, Catacutan and Mercado 2001, Pulhin et al. 2007, Gregorio et al. 2008, 2011b, 2017).

Appropriate training of local communities enables them to acquire more experience in seed production. Once confident enough, community members can share their knowledge with other people in their villages. This acquisition of knowledge leads to a greater degree of trust between DENR and local communities, and a greater degree of freedom in the 
Literature Bayala, J., M. Dianda, J. Wilson, S. J. Ouédraogo, and K. Sanon. 2009. Predicting field performance of five irrigated tree species using seedling quality assessment in Burkina Faso, West Africa. New Forests 38(3):309-322.

Baynes, J., and N. Gregorio. 2008. Nursery Training for Smallholders: An Evaluation of Two Extension Programs in the Philippines. Small-scale Forestry 7(3-4):387-401.

Baynes, J., J. Herbohn, and W. Dressler. 2016. Power relationships: Their effect on the governance of community forestry in the Philippines. Land Use Policy 54:169-176.

Baynes, J., J. Herbohn, and I. Russell. 2011. The Influence of Farmers' Mental Models on an Agroforestry Extension Program in the Philippines. Small-scale Forestry 10(3):377-387.

Baynes, J., J. Herbohn, C. Smith, R. Fisher, and D. Bray. 2015. Key factors which influence the success of community forestry in developing countries. Global Environmental Change 35:226-238.

Belem, B., B. M. I. Nacoulma, R. Gbangou, S. Kambou, H. H. Hansen, Q. Gausset, S. Lund, A. Raebild, D. Lompo, M. Ouedraogo, I. Theilade, and J. Boussim. 2007. Use of Non Wood Forest Products by local people bordering the "Parc National Kaboré Tambi", Burkina Faso. The Journal of Transdisciplinary Environmental Studies 6(1):21.

Bensel, T. 2008. Fuelwood, deforestation, and land degradation: 10 years of evidence from cebu province, the Philippines. Land Degradation \& Development 19(6):587-605.

Bernaldez, S. O., and E. O. Mangaoang. 2008. Tree Adoption and Nursery and Propagation Practices in Smallholder Upland Farms in Inopacan and Isabel, Leyte, the Philippines. Small-scale Forestry 7(3-4):295-309.

Bertomeu, M. 2002. Growing agroforestry trees: Farmers' experiences with individual and group nurseries in Claveria, Philippines. ICRAF.

Bouda, H.-N., P. Savadogo, D. Tiveau, and B. Ouedraogo. 2011. State, forest and community: challenges of democratically decentralizing forest management in the Centre-West Region of Burkina Faso. Sustainable Development 19(4):275-288.

Carandang, W. M., E. L. Tolentino, and J. M. Roshetko. 2006. Smallholder Tree Nursery Operations in Southern Philippines Supporting Mechanisms for Timber Tree Domestication. Forests, Trees and Livelihoods 16(1):71-83.

Catacutan, D., M. Bertomeu, L. Arbes, C. Duque, and N. Butra. 2008. Fluctuating Fortunes of a Collective Enterprise: The Case of the Agroforestry Tree Seeds Association of Lantapan (ATSAL) in the Philippines. Small-scale Forestry 7(3-4):353-368.

Catacutan, D., and A. R. Mercado. 2001. Technical Innovations and Institution-Building for Sustainable Upland Development: Landcare in the Philippines. Makati city, Philippines.

Coulibaly-Lingani, P., P. Savadogo, M. Tigabu, and P.-C. Oden. 2011. Factors influencing people's participation in the forest management program in Burkina Faso, West Africa. Forest Policy and Economics 13(4):292-302.

Dahal, G. R., and D. Capistrano. 2006. Forest governance and institutional structure: an ignored dimension of community based forest management in the Philippines. International Forestry Review 8(4):377-394.

Edralin, D. I., and A. Mercado. 2010. Profiling tree nurseries in northern Mindanao, the Philippines. Annals of Tropical Research 32(2):15-25.

Emtage, N., and J. Suh. 2004. Socio-economic factors affecting smallholder tree planting and management intentions in Leyte Province, Philippines. Small-scale Forest Economics, Management and Policy 3(2):257-270.

Etongo, D., I. Djenontin, M. Kanninen, and K. Fobissie. 2015. Smallholders' Tree Planting Activity in the Ziro Province, Southern Burkina Faso: Impacts on Livelihood and Policy Implications. Forests 6(12):2655-2677.

Germano, E. M., E. G. Tan, and E. Cedamon. 2007. Assessment of Tree Registration in Leyte and Biliran Islands. Annals of Tropical Research 3(29):40-48.

Gijsbers, H. J. M., J. J. Kessler, and M. K. Knevel. 1994. Dynamics and natural regeneration of woody species in farmed parklands in the Sahel region (Province of Passore, Burkina Faso). Forest Ecology and Management 64(1):1-12.

Graudal, L. 1998. The Functions and Role of a National Tree Seed Center. Page 11 Vers une approche régionale des ressources génétiques forestières en Afrique sub-saharienne. Actes du premier atelier régional de formation sur la conservation et I'utilisation durable des ressources génétiques en Afrique de l'Ouest, Afrique Centrale et Madagascar. Institut international des ressources phytogénétiques, Ouagadougou, Burkina Faso. 
Gravoso, R. S., N. O. Gregorio, M. A. D. Gerona, M. N. V. Seriño, S. R. Harrison, H. V. Pajaron, and J. V. Godoy. 2011. Development and Implementation of a Forest Nursery Accreditation Policy at a Local Level in Leyte, Philippines. Small-scale Forestry 10(4):473-488.

Gregorio, N., U. Doydora, S. Harrison, J. Herbohn, and J. Sebua. 2011a. Inventory and assessment of mother trees of indigenous timber species on Leyte Island, The Philippines.

Gregorio, N., S. Harrison, and J. Herbohn. 2010. The Seedling Nursery Survey on Leyte Island, the Philippines. Annals of Tropical Research 32(2):1-14.

Gregorio, N., J. Herbohn, and S. Harrison. 2004. The social and economic factors affecting the role that nurseries play in efficient forest industry in Leyte, Philippines. Annals of Tropical Research 32(2):113-118.

Gregorio, N., J. Herbohn, S. Harrison, A. Pasa, and A. Ferraren. 2017. Regulating the Quality of Seedlings for Forest Restoration: Lessons from the National Greening Program in the Philippines. Small-scale Forestry 16(1):83-102.

Gregorio, N., J. Herbohn, S. Harrison, and C. Smith. 2015. A systems approach to improving the quality of tree seedlings for agroforestry, tree farming and reforestation in the Philippines. Land Use Policy 47:29-41.

Gregorio, N. O., S. Harrison, and J. Herbohn. 2008. Enhancing Tree Seedling Supply to Smallholders in Leyte Province, Philippines: An Evaluation of the Production System of Government Nursery Sector and Support to Smallholder Tree Farmers. Small-scale Forestry 7(3-4):245-261.

Gregorio, N. O., J. Herbohn, and S. Harrison. 2011b. The Operational Effectiveness of the Forest Nursery Sector in Leyte, Philippines. Pages 155-165 Improving the Triple Bottom Line Returns from Small-scale Forestry, Proceedings from an International IUFRO 3.08. Ormoc, the Philippines.

Gregorio, N. O., J. L. Herbohn, and J. K. Vanclay. 2012. Developing establishment guidelines for Shorea palosapis in smallholder plantings in the Philippines. International Forestry Review 14(4):492-501.

Harrison, S., N. F. Emtage, and E. E. Nasayao. 2004. Past and present forestry support programs in the Philippines, and lessons for the future. Small-scale Forest Economics, Management and Policy 3(3):303-317.

Harrison, S., N. Gregorio, and J. Herbohn. 2008. A Critical Overview of Forestry Seedling Production Policies and Practices in Relation to Smallholder Forestry in Developing Countries. Small-scale Forestry 7(3-4):207-223.

Kadda, A. S., A. M. Venus, D. B. Lataza, and M. R. E. Solis. 2008. Operational Effectiveness of Centralized Nursery for SmallScale Forestry in San Carlos City, Negros Occidental, the Philippines: Lessons Learned in Seedling Production for Commercial Energy Crop Plantations. Small-scale Forestry 7(3-4):319-331.

Kambire, H., I. Djenontin, A. Kabore, H. Djoudi, M. Balinga, M. Zida, and S. Assembe-Mvondo. 2015. La REDD+ et l'adaptation aux changements climatiques au Burkina Faso: Causes, agents et institutions. Center for International Forestry Research (CIFOR).

Le, H. D., C. Smith, and J. Herbohn. 2014. What drives the success of reforestation projects in tropical developing countries? The case of the Philippines. Global Environmental Change 24:334-348.

Martin, F. S., and M. van Noordwijk. 2009. Trade-offs analysis for possible timber-based agroforestry scenarios using native trees in the Philippines. Agroforestry Systems 76(3):555-567.

Mercado, A. R., and C. Duque-Piñon. 2008. Tree Seedling Production Systems in Northern Mindanao, Philippines. Small-scale Forestry 7(3-4):225-243.

Mercado, A. R., D. I. Edralin, and S. Harrison. 2010. Techinical and financial aspects of clonally propagated rubber planting stock for rubber agroforestry in Mindanao.

Nguyen, H., D. Lamb, J. Herbohn, and J. Firn. 2014. Designing Mixed Species Tree Plantations for the Tropics: Balancing Ecological Attributes of Species with Landholder Preferences in the Philippines. PLoS ONE 9(4):1-11.

Peque, D., and D. Hölscher. 2014. Rare tree species in nurseries across the Visayas, Philippines. International Journal of Biodiversity and Conservation 6(8):589-599.

Pulhin, J. M., M. Inoue, and T. Enters. 2007. Three decades of community-based forest management in the Philippines: emerging lessons for sustainable and equitable forest management. International Forestry Review 9(4):865-883. 
Raebild, A., B. Bassirou, J. P. B. Lilles $\varnothing$, E.-L. Yago, and P. Damas. 2004. Farmers' planting practices in Burkina Faso: a survey carried out by the project "Improved Seed Supply for Agroforestry in African Countries." Forest and Landscapes, University of Copenhagen.

Russell, I., E. Mangaoang, S. Harrison, J. Herbohn, and J. Baynes. 2011. An approach to improving the flow of information for forestry regulation in the Philippines: trees for life and livelihood.

Savadogo, S., A. Ouedraogo, and A. Thiombiano. 2012. Diversité et enjeux de conservation des bois sacrés en société Mossi (Burkina Faso) face aux mutations socioculturelles actuelles. International Journal of Biological and Chemical Sciences 5(4):1639-1658.

Schneider, T., M. S. Ashton, F. Montagnini, and P. P. Milan. 2014. Growth performance of sixty tree species in smallholder reforestation trials on Leyte, Philippines. New Forests 45(1):83-96.

Schumann, K., R. Wittig, A. Thiombiano, U. Becker, and K. Hahn. 2012. Uses, management, and population status of the baobab in eastern Burkina Faso. Agroforestry Systems 85(2):263-278.

Tankoano, B., M. Hien, N. H. Dibi, Z. Sanon, J. T. Yameogo, and I. Somda. 2015. Dynamique spatio-temporelle des savanes boisées de la forêt classée de Tiogo au Burkina Faso. International Journal of Biological and Chemical Sciences 9(4):19832000.

Thiombiano, D. N. E., N. Lamien, A. M. Castro-Euler, B. Vinceti, D. Agundez, and I. J. Boussim. 2013. Local Communities Demand for Food Tree Species and the Potentialities of Their Landscapes in Two Ecological Zones of Burkina Faso. Open Journal of Forestry 03(03):79-87.

Valette, M., B. Vinceti, D. Traoré, A. T. Traoré, E. L. Yago-Ouattara, and F. Kaguembèga-Müller. 2019. How Diverse is Tree Planting in the Central Plateau of Burkina Faso? Comparing Small-Scale Restoration with Other Planting Initiatives. Forests 10(3):227.

Vallino, E. 2009. Community Based Management of a Protected Area: the case of GEPRENAF in Burkina Faso. International Journal of Social Forestry 2(1):24-42.

Westholm, L., and S. Arora-Jonsson. 2015. Defining Solutions, Finding Problems: Deforestation, Gender, and REDD+ in Burkina Faso. Conservation and Society 13(2):189-199. 
Appendix 3. Appendix 3

Please click here to download file 'appendix 3.xlsx'. 